\title{
Bevizio režimo tarp ES ir Rusijos poveikio vertinimas: Lietuvos atvejis
}

Studijoje siekiama įvertinti galimo bevizio režimo tarp Europos Sąjungos ir Rusijos Federacijos poveikį Lietuvos vidaus, užsienio reikalų, muitinès bei pasienio kontrolès sistemoms. Tyrime bus siekiama išanalizuoti tokio režimo poveikị legalios ir nelegalios migracijos mastams, nusikalstamumo lygiui, valstybès sienos apsaugos sistemai, policijos veiklos organizavimui, Lietuvos nelegalios migracijos valdymo sistemai, finansinę naštą Lietuvos prieglobsčio sistemai bei apskaičiuoti bendras ir būsimas finansines sąnaudas. Analizëje naudojami empiriniai duomenys susideda iš interviu su vidaus ir užsienio reikalų ministeriju bei su jomis susijusių institucijų (Policijos departamento prie VRM, Migracijos departamento prie VRM, Valstybes sienos apsaugos tarnybos prie VRM, Muitinès departamento prie Finansų ministerijos, Pasienio kontroles punktų direkcijos prie Susisiekimo ministerijos) pareigūnais, statistinių duomenų bei anksčiau atliktų tyrimų apie bevizị režimą. Studiją sudaro šios penkios dalys: politinio konteksto beviziam režimui įvesti ịvertinimas, jo poveikio aukščiau minètoms valstybès institucijoms analizè, bendros finansinès naštos dẻl galimo bevizio režimo apskaičiavimas, išvados bei rekomendacijos. Tyrimo tikslas ir uždaviniai apima specifinius veiksnius bei jų poveikį, tačiau neatmetama, kad kompleksiškoje socialinëje realybëje gali pasireikšti ir kitų veiksnių, nętrauktų i studiją, poveikis, kuris čia nèra aptariamas dẻl tyrimo apimties ribotumo. Studijos išvados ir pasiūlymai iš dalies orientuojami į ateities perspektyvas, o tai metodologiškai apsunkina tikslius sąnaudų vertinimus. Be to, tyrime nèra apskaičiuojama galima bevizio režimo nauda. Išvadose buvo nustatyti neigiamos įtakos aspektai dèl ES - Rusijos bevizio režimo įvedimo: jis panaikintų specialiosios Kaliningrado tranzito schemos poreikį ir šios schemos finansavimą, tikètina, didètų bendras nusikalstamumas, suaktyvètų organizuoto nusikalstamumo grupuočių veikla bei plèstųsi terorizmo ir prekybos žmonèmis grèsmès. Sąnaudos, susiję su nuostoliais dèl sumažejusio ES finansavimo, negautos lešos bei išaugę institucijų stiprinimo poreikiai sudarytų 16-17 milijonų litų metinių išlaidų, neskaičiuojant papildomų sąnaudų ir ateities projektų, kurių suma gali siekti nuo 40 iki 85 milijonų litų.

\footnotetext{
${ }^{*}$ Dr. Mindaugas Jurkynas - Vilniaus universiteto Tarptautinių santykių ir politikos mokslu instituto Europos studijų katedros docentas. Adresas korespondencijai: Vokiečiu g. 10, 01130 Vilnius, tel. 85 2514139, el. paštas - mindaugas.jurkynas@tspmi.vu.lt. Vilija Gelažauskaité - Vilniaus universiteto Tarptautinių santykių ir politikos mokslų instituto Europos studijų magistranté, Švietimo ir mokslo ministerijos Tarptautinio bendradarbiavimo skyriaus vyriausioji specialiste. Adresas korespondencijai: A. Volano g. 2/7-231, 01516 Vilnius, tel. 85 2191251, el. paštas - vilija.gelazauskaite@gmail.com
} 


\section{Ivadas}

Vizų režimo tarp Europos Sąjungos bei Rusijos Federacijos panaikinimas - prasidejęs procesas, daugiausiai inicijuotas pačios Rusijos. ${ }^{1}$ Svarbių ekonominių ar socialinių motyvų beviziam režimui atsirasti nera: tai veikiau Rusijos statuso ir simbolio klausimas, kuris, atsiradęs Rusijos politinëje darbotvarkëje, yra aktyviai „stumiamas“ santykiuose su ES. ${ }^{2}$ Rusijos pareigūnai teigia, kad ES ir Rusija, svarstydamos šị klausimą, pastaruoju metu pereina i ’operatyviają fazę“, aptardamos biometriniu pasų ir readmisijos susitarimo igyvendinimo klausimus. ${ }^{3}$ Bevizio režimo ịvedimo klausimas buvo iškeltas dar 2003 m. Sankt Peterburge vykusiame vienuoliktame Europos Sąungos ir Rusijos vadovų susitikime. Lietuva taip pat yra šio proceso dalyvè, nes jai, kaip visateisei Europos Sajungos narei, aktualūs bendrieji Sajungos sudaromi susitarimai su trečiosiomis šalimis ir iš jų kylantys teisiniai įsipareigojimai. Svarbu pažymèti, kad tokie susitarimai gali suponuoti ịvairaus pobūdžio pasekmes, kurių valdymas, neigiamų aspektų neutralizavimas ar galima nauda tampa svarbiais bevizio režimo ịvedimo aspektais.

Šis poveikio vertinimo tyrimas yra aktualus dèl politinių, saugumo ir techninių-finansinių priežasčių. Politiškai ES-Rusijos santykių lygmenyje šis procesas jau prasidëjęs ir Lietuvai, kaip ES narei, atsakingai už ES išorinę sieną su Rusija, svarbu žinoti dinamišką geopolitinę situaciją bei jos pasekmes. Žvelgiant iš „minkštojo “ saugumo perspektyvos, galimos bendros bevizio režimo sąnaudos, o ypač studijoje tiriamas poveikis vidaus saugumui, lieka nepakankamai įvertinti. Tyrimo metu surinkta informacija bei rekomendacijos gali tapti naudingu ịrankiu formuoti Lietuvos institucijų argumentacijai derybose dèl bevizio režimo įvedimo, numatant įvairaus pobūdžio kompensacines priemones. Logiška, kad studiją apie ES-Rusijos bevizio režimo poveikị Lietuvai galima laikyti svarbia pirmine analize, padèsiančia užtikrinti geresnį esamos situacijos suvokimą ir tam tikrų gairių ruošiant ar tobulinant Lietuvos derybines pozicijas tiek dèl ES-Rusijos bevizio režimo, tiek dèl ES finansinès 2014-2020 m. perspektyvos, projektavimą. Studija taip pat gali

\footnotetext{
${ }^{1}$ Studijos autoriai dèkoja dviems anoniminiams recenzentams už pastabas, VU TSPMI studentui Martynui Bieliakui už techninę pagalbą, tekste minètų institucijų atstovams už pasiūlymus, duomenis bei bendradarbiavimą ir Ministro Pirmininko tarnybai už tyrimo koordinavimą. Tyrimas finansuotas Ministro Pirmininko tarnybos vykdomo projekto „Lietuvos - Europos Sajungos reikalų sistemos efektyvumo didinimas (LESSED)“ (Nr. VP1-4.2-VRM-05-V-02-001) lěšomis. Projektas „Lietuvos - Europos Sajungos reikalų sistemos efektyvumo didinimas (LESSED)“ vykdomas pagal 2007-2013 m. Žmogiškųjų išteklių plettros veiksmų programos 4 prioriteto „Administracinių gebejjimų stiprinimas ir viešojo administravimo efektyvumo didinimas“ igyvendinimo priemonę VP1-4.2-VRM-05-V „Geresnis Europos Sąjungos politikų igyvendinimas“.

${ }^{2}$ Interviu su Lietuvos Respublikos užsienio reikalų ministerijos Rytų kaimynystès politikos departamento Rusijos skyriaus III sekretore p. Lina Sučilaite, $2011 \mathrm{~m}$. sausio $20 \mathrm{~d}$.

${ }^{3}$ BNS, Bevizis režimas bus viena svarbiausiu Rusijos ir ES viršüniu susitikimo temu, sako Čizovas, $2010 \mathrm{~m}$. gruodžio 2 d., <http://myep.delfi.lt/news/bevizis-rezimas-bus-viena-svarbiausiu-rusijos-ir-es-virsuniu-susitikimo-temu-sako-cizovas.d?id=39253527>, 20122010.
} 
būti naudinga ir VRM pozicijoms parengti, reaguojant į $2011 \mathrm{~m}$. sausio pradžioje sudarytą Europos Komisijos klausimyną, į kurị reikia atsakyti iki 2011 m. kovo 6 d. ${ }^{4}$ Galiausiai tyrimo aktualumui papildomą kontekstą sudaro ir tam tikri vidaus politinio gyvenimo elementai: remiantis nuomoniu apklausomis, Lietuvos gyventojai, vertindami šalies užsienio politiką, palankiausiai žiūri į valstybès vadovų pastangas normalizuoti santykius su Rusija. ${ }^{5}$

Vertinant tyrimo naujumą, verta pažymèti, kad iki šiol praktiškai nèra išsamesnių studiju apie ES-Rusijos bevizio režimo poveikį Lietuvai ar atskiroms valstybès gyvenimo sritims, išskyrus trumpus vidinius VRM ir URM pasvarstymus apie galimas bevizio režimo išlaidas. ${ }^{6}$. Egzistuoja daugiausia bendresnio pobūdžio analizès, kaip antai, M. M. Salminen ir A. Moshes (2009) studijoje tiriamos Rusijos-ES bevizio režimo perspektyvos, analizuojami penki atvejai (Suomija, Vokietija, Italija, Estija, Lenkija), dabartinis vizu režimas ir su bevizio režimo ịvedimu susijusios politinès, saugumo ir technines problemos. Tyrimo išvadose pabrěžiama, kad bevizis režimas tarp ES ir Rusijos yra abipusiškai naudingas ir siektinas, nes tarp ES ir Rusijos padidëjo keliaujančiu asmenų skaičius, o į Rusijos piliečius žiūrima kaip ị patikimus ir gerus klientus. Galiausiai teigiama, kad Rusijos modernizacijai reikia Europos kapitalo ir žinių - tai reikalauja lengvesnių žmonių komunikacijos sąlygų. Studijoje teigiama, kad dabartinis vizų režimas, savo ruožtu, menkina strateginę ES-Rusijos partnerystę.

Šio mažos apimties tyrimo tikslas - ịvertinti numatomo bevizio režimo tarp Europos Sąungos ir Rusijos Federacijos įvedimo poveikị Lietuvos vidaus reikalu sistemai. Siekiant igyvendinti suformuluotą tikslą, tyrime iškeliamas užsakyme nustatytas bendrasis uždavinys - nustatyti bei kokybiškai ir kiekybiškai įvertinti bevizio režimo tarp ES ir Rusijos Federacijos įvedimo pasekmes bei pateikti pagrịstus siūlymus ir rekomendacijas dèl galimo šių pasekmių valdymo ar neutralizavimo. Šalia bendrojo uždavinio yra išskiriami konkretūs papildomi uždaviniai, žymintys detalu galimo Europos Sąjungos ir Rusijos bevizio režimo poveikio tyrimo atskiroms šalies vidaus reikalų sistemos sritims vykdymą:

- İvertinti galimą bevizio režimo tarp Europos Sąungos ir Rusijos Federacijos poveiki Lietuvos socialinei aplinkai: legalios ir nelegalios migracijos mastams, nusikalstamumo lygiui;

\footnotetext{
${ }^{4}$ Public Consultation on EU Funding in the Area of Home Affairs, <http://ec.europa.eu/home-affairs/news/consulting_public/consulting_0020_en.htm>. 07022011

${ }^{5}$ BNS, Pastangos normalizuoti santykius su Rusija vertinamos palankiai, $2011 \mathrm{~m}$. sausio $24 \mathrm{~d}$., <http://www.delfi.lt/news/daily/lithuania/pastangos-normalizuoti-santykius-su-rusija-vertinamos-palankiai.d?id=41181519>, 25012011.

${ }^{6}$ Lietuvos Respublikos vidaus reikalų ministerija, Vizu režimo tarp ES ir Rusijos panaikinimo poveikio Lietuvai vertinimas, 2010 m. lapkritis (dokumentas gautas iš Lietuvos Respublikos vidaus reikalų ministerijos Tarptautinio bendradarbiavimo departamento vyresniosios specialistes p. Irinos Voinilkos, $2011 \mathrm{~m}$. sausio $26 \mathrm{~d}$.)
} 
- İvertinti galimas bevizio režimo tarp Europos Sajungos ir Rusijos Federacijos įvedimo pasekmes valstybés sienos apsaugos sistemai: Valstybès sienos apsaugos tarnybos veiklos organizavimui, finansinių ir žmogiškųjų išteklių poreikiui;

- İvertinti galimas bevizio režimo tarp Europos Sajungos ir Rusijos Federacijos įvedimo pasekmes vidaus saugumui užtikrinti: policijos veiklos organizavimui, finansinių ir žmogiškųjų išteklių poreikiui;

- İvertinti bevizio režimo tarp Europos Sajungos ir Rusijos Federacijos administracinę ir finansinę naštą Lietuvos nelegalios migracijos valdymo sistemai;

- İvertinti bevizio režimo tarp Europos Sąungos ir Rusijos Federacijos administracinę ir finansinę naštą Lietuvos prieglobsčio sistemai;

- Apskaičiuoti bendrą finansinę naštą, teksiančią Lietuvai bevizio režimo tarp Europos Sajungos ir Rusijos Federacijos įvedimo atveju.

Tyrimo rezultatai padètų nustatyti problemas/ǐšǔkukius, su kuriais susidurs Lietuvos valstybès sienos apsaugos sistema, LRM sistema, Lietuvos migracijos valdymo sistema, Lietuvos policijos ịstaigos bevizio režimo tarp ES ir RF įvedimo atveju, leistų pasiūlyti galimus numatomų problemų sprendimo/neutralizavimo būdus ir iššūkiu valdymo priemones bei pateikti galimą ju ịgyvendinimo finansinę išraišką.

Atsižvelgiant į studijos specifiką bei siekiant ịgyvendinti iškeltą tikslą, tyrime naudojamos kelios duomenų rinkimo ir analizes metodologijos, besiremiančios kokybiniu socialinių mokslų tyrimo metodu - atvejo studija. Atvejo studija, kaip pagrindinis tyrimo įrankis, igalinantis visapusiškai ir giliai analizuoti nedideli kiekį tiriamųjų objektų, padeda atskleisti Lietuvos atvejui būdingą problematiką, tendencijas, nustatyti galimas bevizio režimo tarp Europos Sąungos bei Rusijos Federacijos pasekmes Lietuvos vidaus reikalų ir LRM sistemoms.

Studijos autoriai pripažįsta, jog tyrime dẻl suformuluotų empirinių užduočiu tikslingai nèra ieškota teorinio pagrindo ar pagrindų ir papildomos informacijos, kuri pagrịstų interviu metu surinktą medžiagą, kadangi studijoje išlieka kritiškas institucijų nuomonę atspindinčios informacijos, gautos interviu metu, vertinimas. ${ }^{7}$

Siekiant įvairiapusiškai ir objektyviai įvertinti bevizio režimo tarp Europos Sajungos bei Rusijos Federacijos poveiki, šiame tyrime naudojami empiriniai duomenys, gauti iš pirminių šaltinių, analizuojant politinę situaciją, statistinius duomenis, interviu su Lietuvos Respublikos vidaus ir užsienio reikalų ministerijų bei su jomis susijusių institucijų (Policijos departamento prie VRM, Migracijos departamento prie VRM, Valstybés sienos apsaugos tarnybos prie VRM, Muitinés departamento prie Finansų ministerijos, Pasienio kontrolès punktų direkcijos prie

\footnotetext{
${ }^{7}$ Lietuvos Respublikos Ministro Pirmininko kancleris Deividas Matulionis yra davęs leidimą spausdinti šią studiją.
} 
Susisiekimo ministerijos) pareigūnais; antrinių šaltinių, t.y. iš kitų anksčiau atliktų analizių apie bevizị režimą ir jo aspektus.

Tyrimo sudedamosios dalys apima politinị bevizio režimo įvedimo kontekstą, bevizio režimo poveiki Lietuvos socialinei aplinkai, nelegalios migracijos valdymo ir prieglobsčio sistemai, valstybès sienos apsaugos ir muitinès sistemoms, vidaus saugumo užtikrinimui, bendros finansinès naštos Lietuvai dẻl bevizio režimo įvedimo apskaičiavimą, išvadas bei rekomendacijas.

\section{Politinis bevizio režimo ịvedimo kontekstas}

Šiame skyriuje bus bandoma trumpai apžvelgti Rusijos ir Europos Sąungos bevizio režimo įvedimo kontekstą, siejant ji su Lietuvos pozicijos ypatybèmis. Pirmiausia svarbu pažymèti, kad ES-Rusijos bevizio režimo įvedimo klausimas žymi prasidejjusi politini procesą, kurio ištakos, kaip jau buvo minèta, susijusios su 2003 m. Sankt Peterburge vykusiu ES ir Rusijos vadovų susitikimu. Śiame vienuoliktame eiliniame ES ir Rusijos viršūnių susitikime ypatingos svarbos igijo siekis perkelti dvišalius Sąjungos bei Rusijos Federacijos santykius ị kokybiškai naują lygmenį. Paskelbta deklaracija, numatanti plèsti bendradarbiavimą keturiose srityse: ekonominëje, laisvès, saugumo ir teisingumo, mokslo ir švietimo bei išorinio saugumo. ${ }^{8}$ Būtent šioje deklaracijoje iškeltas tyrimui aktualus vizų režimo palengvinimo klausimas, kuriam spręsti numatyta ilgalaike perspektyva. Taigi bevizio režimo įvedimas - vienas iš ES-Rusijos „partnerystés modernizacijos“ ir pačios Rusijos „modernizacijos“ aspektų, svarbus kaip ilgalaikès bendradarbiavimo perspektyvos tikslas ${ }^{9}$. Bevizio režimo įvedimo proceso pradžią galima laikyti svarbiu žingsniu link ES-Rusijos strateginès partnerystès stiprinimo ${ }^{10}$.

Lietuvos poziciją, kurios šalyje nesupriešina skirtingos institucinès ar politinès nuomonès, ES-Rusijos bevizio režimo klausimu galima apibūdinti kaip nuosaikų pritarimą ES nuostatai, kad vizų panaikinimas Rusijai ateityje yra galimas, išskiriant keletą reikšmingų aspektų, kurių igyvendinimas Lietuvoje laikomas svarbiu vizų panaikinimo proceso pažangos rodikliu. Vienas iš tokių aspektų yra techninis: su bevizio režimo įvedimu susijusių priemonių igyvendinimas ir su tuo susijusios pažangos matavimas. Tai yra koncentravimasis į proceso ilgalaikiškumą ir gebejjimą užsitikrinti, jog bevizis režimas Rusijai nebus įvestas, neigyvendinus visų

\footnotetext{
${ }^{8}$ Vitkus G., „Rusijos-JAV-ES trikampis ir mažesnès valstybès 2003-2004 metais“, Lietuvos metine strategine apžvalga 2004, p. 144.

${ }^{9}$ Kirvelyte L., „Rusijos B planas“, Vilnius, 2010 m. birželio 11 d., <http://www.atgimimas.lt/Pasaulyje/2010metai-birzelio/Rusijos-B-planas>, 21012011.

${ }^{10}$ Interviu su p. Lina Sučilaite (2 išnaša).
} 
reikiamų priemonių bei jam adekvačiai nepasiruošus. ${ }^{11}$ Antrasis, labiau politinis aspektas, sietinas su Rytų partnerystes šalių nediskriminavimo perspektyva ${ }^{12}$. Nors tokių šalių pasirengimo stadija ir įdirbio laipsnis, siekiant įsivesti bevizį režimą su ES, yra labai nevienodas (Ukraina, Moldova yra pasiekusios santykinai aukštą pažangos laipsni, o tokios šalys kaip Gruzija, Baltarusija, Armėnija, Azerbaidžanas - atsilieka kur kas labiau), tačiau tiek Lietuvai, tiek daugeliui kitų naujųjų ES narių svarbu pasiekti, kad bevizis režimas Rusijai nebūtų įvestas anksčiau nei Rytų partnerystès šalims ${ }^{13}$.

Bene aktyviausios pastangos priimti galutini susitarimo projektą, skirtą įvesti ES-Rusijos beviziam režimui, buvo sutelktos Ispanijos pirmininkavimo Sąjungai metu, 2010 m. pradžioje. Šiame kontekste itin svarbų vaidmenị suvaidino Ispanijos užsienio reikalų ministras Miguelis Angelis Moratinosas, inicijavęs idejją parengti Rusijai tam tikras „kelio gaires“, numatančias ES-Rusijos bevizio režimo liberalizavimą ir galutinị panaikinimą dar Ispanijos pirmininkavimo laikotarpiu. ${ }^{14}$ İsivyravo požiūris, kad bevizio režimo įvedimo sustabdyti nepavyks, todel su Rusijos pažangos procesu susieta vizų panaikinimo perspektyva tapo priimtina alternatyva tiek Lietuvai, tiek kitoms naujosioms ES narèms. Šią procesinę išraišką ir pažangos vertinimo galimybę Lietuvos atveju galima vertinti kaip tam tikrą nuo neigiamų implikacijų atribojantị saugiklį, grịstą konkrečių laiko rẻmų nebuvimu bei dokumentų derinimo baigties neaiškumo aspektu. ${ }^{15}$

Naujosios ES nares kartu su Šiaures šalimis, Didžiąja Britanija, Belgija, Olandija yra tarsi skeptiškųjų ES narių grupe, kuri, nors ir tiesiogiai neprieštarauja minèto bevizio režimo ịvedimui, tačiau laikosi gana nuosaikios bei atsargios pozicijos. Ne vien strateginio, bet ypač operatyvaus bendradarbiavimo plètojimu su Rusijos teisesaugos institucijomis labiausiai suinteresuotos Baltijos šalys, Austrija bei Olandija. Likusių ES narių, pirmiausia Vokietijos ir Prancūzijos, pozicijos gana smarkiai išsiskiria: pirmoji labiau pasisako už kontroliuojamo proceso alternatyvą, o antroji pasižymi kur kas aktyvesniu ir mažiau ị kontroliuojamą procesą orientuotu palaikymu paspartinti bevizio režimo įvedimą. Tokiai Prancūzijos pozicijai gana artima ir pietinių ES šalių, t.y. Ispanijos, Italijos, Portugalijos, Graikijos, Kipro, nuomone - visos šios valstybès kur kas mažiau dèmesio skiria bevizio režimo proceso detalëms. ${ }^{16}$ Visgi Europos Sąjungos nariu pozicijoms yra būdingas bendras „vardiklis“, už kurị pasisako bemaž visos ES šalys. Tai yra tam tikri minimalūs ir

\footnotetext{
${ }^{11}$ Ten pat.

${ }^{12}$ Ten pat.

${ }^{13}$ Kirvelytė (9 išnaša).

${ }^{14}$ BNS, Bevizio režimo su ES siekianti Rusija ruošiasi pasirašyti readmisijos protokolus su Bendrijos šalimis, Vilnius, 2010 m. sausio 23 d., <http://www.delfi.lt/news/daily/world/bevizio-rezimo-su-es-siekianti-rusijaruosiasi-pasirasyti-readmisijos-protokolus-su-bendrijos-salimis.d?id=28149309>, 19122010

${ }^{15}$ Interviu su p. Lina Sučilaite (2 išnaša).

${ }^{16}$ Ten pat.
} 
pirminiai „namų darbai“, kuriuos Rusija turi atlikti, kad būtų pasiekta adekvati pažanga dar prieš bevizio režimo įvedimą: Rusijos įsipareigojimai panaikinti privalomą ES piliečių registravimą Rusijoje bei biometrinių pasų įvedimas. ${ }^{17}$

Analizuojant ES ir Rusijos bevizio režimo įvedimo kontekstą, ne mažiau svarbu įvardyti ir Europos Komisijos nuomonę, mat Komisija atstovauja Sąjungai derybose su Rusija. EK poziciją galima laikyti artima šalių grupei, pasisakančiai už kontroliuojamą procesą ir nuolatinị įsipareigojimų igyvendinimo pažangos vertinimą. ${ }^{18}$ Toks Komisijos ir „atsargiųjų“ narių grupès požiūris gali būti vertinamas kaip „žingsnis po žingsnio“ logika. ${ }^{19}$

Viso derybų proceso metu šalys narès turi tam tikros įtakos, mat dalyvauja ES Tarybos darbo grupèse, įvairiose vertinimo komisijose, raportų analizëje, nors, žinia, didžiųjų ES narių, ypač Prancūzijos ir Vokietijos, pozicijos yra bene svarbiausios. Lietuvos poziciją reikètų vertinti kaip sudedamają bendros ES pozicijos dali, kadangi dvišaliai susitarimai bevizio režimo įvedimo klausimais tarp Lietuvos ir Rusijos nèra formuojami. ${ }^{20}$

Reikia pažymèti, kad vienas iš svarbiausių klausimų Lietuvai ES ir Rusijos derybose dèl vizų panaikinimo gali būti siejamas su Lietuva besiribojančia Kaliningrado sritimi, o tiksliau - su specialiąja Kaliningrado tranzito schema. Bevizio režimo atsiradimas pirmiausia reikštų minètosios schemos veikimo pabaigą, o tai būtų susiję su ES finansavimo nutraukimu bei darbo vietų mažejimu, apie ką bus vèliau rašoma detaliau. Lietuva norètų Kaliningradui suteikti daugiau išskirtinumo bevizio režimo įvedimo procese, ${ }^{21}$ tačiau pastebimas tokio pobūdžio iniciatyvų trūkumas iš Rusijos pusès. ${ }^{22} 23$

\footnotetext{
${ }^{17}$ Interviu su Lietuvos Respublikos vidaus reikalų ministerijos Tarptautinio bendradarbiavimo departamento direktoriumi p. Olegu Skinderskiu, $2011 \mathrm{~m}$. sausio $28 \mathrm{~d}$.

${ }^{18}$ Interviu su p. Lina Sučilaite (2 išnaša).

${ }^{19}$ Bevizio režimo įvedimo proceso metu ES Taryba savo sprendimu nustato ir patvirtina derybų mandato apimtis Komisijai, suteikdama galimybę atstovauti Sąungai tarptautinèse derybose su trečiosiomis šalimis, o tyrime analizuojamu atveju - su Rusija. Galutinis šio proceso rezultatas - dvišales sutarties tarp ES ir Rusijos pasirašymas. Interviu su Lietuvos Respublikos užsienio reikalų ministerijos Konsulinio departamento Šengeno skyriaus vedëju p. Rimgaudu Lošiu, 2011 m. sausio 20 d.

${ }^{20}$ Interviu su p. Lina Sučilaite (2 išnaša).

${ }^{21}$ Ten pat.

${ }^{22}$ Būta pastangų suteikti Kaliningradui ypatingą statusą, kuris leistų kalbèti apie ankstesnị „bevizio režimo“ įvedimą šioje Rusijos dalyje. Tai sietina su Lenkijos ir Rusijos iniciatyvomis pritaikyti bevizị režimą visiems Kaliningrado srities gyventojams. Pasak užsienio reikalų viceministro Evaldo Ignatavičiaus, Lietuva palaike kitokią, labiau su Briuseliu suderintą ir Šengeno sutarties įsipareigojimus atitinkančią poziciją: pasisakyta už idejją, apimančią supaprastintą sienos kirtimo galimybę penkiasdešimt kilometrų atstumu nuo jos gyvenantiems žmonems, tačiau Rusija tokio pobūdžio susitarimo sudaryti nepanoro. Gudavičius S., „Lietuva - Rusijos bevizio režimo ị ES stabdys“, Vilnius, 2010, < http://www.diena.lt/naujienos/lietuva/lietuva-rusijos-beviziorezimo-i-es-stabdys-294945/psl-1>, 19012011.

${ }^{23}$ Tokia vietinio eismo sutartis žymètų tarpinę padètį tarp dabartinès situacijos ir vizų panaikinimo, taigi būtų vertintina pozityviai kaip testas, rodantis, kaip galètų veikti bevizio režimo schema. Interviu su p. Olegu Skinderskiu, $2011 \mathrm{~m}$. sausio $28 \mathrm{~d}$. (17 išnaša).
} 
Vizų panaikinimas nèra tapatus vieningos erdvès sukūrimui, tad šio proceso galutinis rezultatas turètų reikšti ne kontrolès panaikinimą, bet kontrolès formos pakitimą: panaikinama dviejų kontrolès lygių sistema, o naujoji sistema sutelkiama i pasienio kontrolę. ${ }^{24}$ Tokiu būdu vis dar išlieka tam tikri apsaugos nuo nepageidaujamų veiksnių mechanizmai (pvz., apribojimai dèl buvimo laiko kitoje šalyje). Reikia pažymèti, kad konsulinès kontrolès atsisakymas bevizio režimo atveju reikštu, kaip vèliau teigiama tyrime, didesnio masto piliečių tikrinimus pasienyje. ${ }^{25}$

\section{Bevizio režimo poveikis}

\subsection{Bevizio režimo poveikis Lietuvos socialinei aplinkai, nelega- lios migracijos valdymo ir prieglobsčio sistemai}

Ankstesniame skyriuje aptarti aspektai pateikia svarbų kontekstą bevizio režimo įvedimo klausimais. Kokie galètų būti konkretūs vizų režimo panaikinimo iššūkiai Lietuvos vidaus reikalų sistemai, ką suponuoja tyrimo tikslas ir šiek tiek plačiau, bus analizuojama kituose skyriuose ir poskyriuose.

Siekiant įvertinti bevizio režimo tarp Europos Sąungos ir Rusijos poveikị, svarbu paanalizuoti vizų schemos panaikinimo įtaką Lietuvos socialinei aplinkai, koncentruojantis į legalios ir nelegalios migracijos tendencijas. Remiantis Migracijos departamento prognozemis, îvedus bevizị režimą tarp Europos Sąjungos ir Rusijos, migracijos srautai turètų nemažèti: priešingai, prognozuojama, kad pasireikštų didejjimo tendencijos. Rusija yra viena svarbiausių Europos Sąjungai nepriklausančių valstybių, iš kurios pastebimi santykinai dideli migracijos srautai į ES šalis. Svarbu pažymèti, kad pastebimas ir atvirkštinis migracijos srautas: Lietuvos atveju Rusija yra bene pagrindine ES nepriklausanti šalis, į kurią išvyksta gyventi Lietuvos Respublikos piliečiai. Pavyzdžiui, 2004-2009 m. laikotarpiu į Rusiją gyventi kasmet vidutiniškai išvykdavo 487 Lietuvos Respublikos piliečiai, o 2006-2009 m. jau matyti tokio emigracijos srauto didejimo tendencijos ${ }^{26}$. Kaip rodo minetuose metraščiuose fiksuojami duomenys, 2001-2004 m. laikotarpiu Rusijos piliečiai sudare didžiausią dalị užsieniečiu, kuriems buvo išduotas leidimas nuolat gyventi

\footnotetext{
${ }^{24}$ Interviu su p. Rimgaudu Lošiu, 2011 m. sausio 20 d. (19 išnaša).

${ }^{25}$ Esminis padidejusių patikros mastų kriterijus - vieno keleivio tikrinimo laikas, kurio optimizavimui galimai tektų pasitelkti didesnị pasienyje tikrinimus atliekančių institucijų žmogiškųjų išteklių skaičių, o tai reikštų papildomų sąnaudų atsiradimą.

26 Šaltiniai: 2004 m. Migracijos metraštis, 2005 m. Migracijos metraštis, 2006 m. Migracijos metraštis, 2007 m. Migracijos metraštis, 2008 m. Migracijos metraštis, 2009 m. Migracijos metraštis, <www.migracija.lt>, 2601 2011.
} 
Lietuvoje (per metus vidutiniškai 47 proc. visų išduotų leidimų)27. 2005-2009 m. laikotarpiu išliko panašios tendencijos: Rusijos piliečiams buvo suteikta daugiausia ilgalaikių leidimu gyventi Europos Sąungoje, tačiau procentinis metinis vidurkis sumažejo iki 37 proc. $^{28}$ Tikètina, kad panaikinus vizas dèl paprastesnès sienos kirtimo procedūros abipuses migracijos tendencijos galètų dar sustiprèti. Preliminariais Policijos departamento duomenimis, laukiamas metinis migracijos iš Rusijos srautas padidettu maždaug 3-3,5 karto (per Lietuvą ir kitas ES šalis), o tai reikštų, kad per metus į Lietuvos Respubliką vidutiniškai turetų atvykti apie 3,5 mln. Rusijos piliečių (plg. 2010 m. ị Lietuvą iš šios šalies atvyko daugiau nei 1,1 $\mathrm{mln}$. jos piliečių), kuriems bus būtina atlikti transporto priemonių ir gabenamy daiktų (prekiu) muitinį tikrinimą. Žinoma, laukiama ekonominès migracijos mastų augimo, ${ }^{29}$ nors tokią asmenų srautų iš Rusijos padidejimo prognozę reiketų vertinti atsargiai, nes ji neturi realaus pagrindimo - tai yra visu prognozių visuomeniniu procesu metodologijoje silpnoji vieta.

Dar viena svarbi nelegalios migracijos mastų sudedamoji dalis $-\mathfrak{i}$ Lietuvos Respubliką atvykusių Rusijos piliečių paveluotas išvykimas iš šalies. I̦vedus bevizi režimą paaštrètų ir neteisèto buvimo šalyje problemos, ypač pasireiškiančios piktnaudžiavimu laiku - t.y. per šešis menesius neišvykti iš Lietuvos Respublikos. ${ }^{30}$ Pateikiamos prognozès rodo, kad bevizio režimo ịvedimas padidintu nelegalios migracijos riziką, kadangi Rusijos piliečiai įvairiais laikotarpiais sudarydavo didžiąją dalį visų nelegalių migrantų ${ }^{31}$ Visgi tai nèra pakankamas pagrindas prognozuoti nelegalios migracijos padidëjimą įvedus bevizį režimą. Antai, pasak Migracijos departamento atstovo, esant beviziam režimui nelegalios migracijos kiekis neturètu pastebimai padidèti, nes nelegalūs migrantai dažnai būna kontrabanda ${ }^{32}$ užsiiman-

\footnotetext{
${ }^{27}$ Migracijos departamentas prie Lietuvos Respublikos vidaus reikalų ministerijos, 2004 m. Migracijos metraštis, Vilnius, 2005, p. 49.

${ }^{28}$ Migracijos departamentas prie Lietuvos Respublikos vidaus reikalų ministerijos, 2009 m. Migracijos metraštis, Vilnius, 2010, p. 60.

${ }^{29}$ Interviu su Policijos departamento prie Lietuvos Respublikos vidaus reikalų ministerijos tarptautinio bendradarbiavimo valdybos vyriausiuoju specialistu p. Aleksandr Valentij, $2011 \mathrm{~m}$. vasario $9 \mathrm{~d}$. İvedus bevizị režimą paprastèja LR sienos kirtimo procedūra RF piliečiams ir RF piliečiams, norintiems patekti į LR teritoriją, nereikès atlikti vizos išdavimo procedūros. Bevizis režimas darytų ịtakos pasienio gyventojų apisprendimui atvykti į LR teritoriją dèl galimybès atgabenti pigesnes prekes ar organizuoti akcizinių prekių kontrabandos kanalus.

${ }^{30}$ Interviu su Migracijos departamento prie Vidaus reikalų ministerijos Užsieniečių reikalų skyriaus vedëju p. Antanu Turčinu, $2011 \mathrm{~m}$. sausio $27 \mathrm{~d}$.

${ }^{31}$ Interviu su Valstybès sienos apsaugos tarnybos prie Vidaus reikalų ministerijos Veiklos organizavimo valdybos Pasienio kontroles skyriaus vyresniuoju specialistu p. Alvydu Pumpučiu, $2011 \mathrm{~m}$. sausio 27 d.

32 Apytiksliais apskaičiavimais 2010 m. muitinès užkardyta žala dẻl neteisèto rusiškų cigarečių ịvežimo siekia $45 \mathrm{mln}$. Lt.
} 
tys asmenys, kurių aktyvumo bevizis režimas neturètų paveikti, ${ }^{33}$ nebent teoriškai kontrabanda būtų susieta su didesniu Rusijos piliečių, įvažiavusių i lietuvą, skaičiumi. Kita vertus, kontrabandos srautai ES, ir visų pirma Lietuvos kryptimi, yra nulemti skirtingų atitinkamų prekių kainų ir pragyvenimo lygio, kurie yra bene svarbiausi veiksniai nelegalios prekybos ir kontrabandos abipus sienos atvejais.

Oficiali statistika rodo, kad nors 1995-2010 m. laikotarpiu valstybés sienos su Rusija pažeidimų skaičius kito nepastoviai (vidutiniškai tai sudare 155 sienos pažeidimus per metus), tačiau pastaruoju metu (t.y. 2008-2010 m.) jis auga. ${ }^{34}$ Per paskutinius penkiolika metų Lietuvos Respublikos pasienyje sulaikytų įtariamųjų Rusijos piliečių skaičius svyravo (nuo 2 asmenų 1995 m. iki 138 asmenų 2001 m.), tačiau 2006-2010 m. pastebimos sulaikymo mastų didejjimo tendencijos, kurios taip pat gali rodyti didèsiančią nusikalstamumo grèsmès tikimybę, jei bus įvestas bevizis režimas ${ }^{35}$. Dar vienas svarbus aspektas, susijęs su galima augsiančio nusikalstamumo tiek Lietuvoje, tiek Europos Sąungoje rizika, apima Rusijoje egzistuojančias kelionès dokumentų klastojimo, dokumentų saugumo ir biometrinių identifikatorių nebuvimo problemas. ${ }^{36}$ Šių problemų egzistavimas bei siekis sukontroliuoti jų neigiamas pasekmes Lietuvos vidaus saugumui užtikrinti galètų paskatinti didesnių nei ịprasta finansinių sąnaudų atsiradimą, apie ką bus rašoma vèliau.

Svarbu akcentuoti ir nelegalų akcizinių prekių gabenimą per LietuvosRusijos sieną. Statistiniai duomenys rodo, kad 1997-2010 m. didžiausias kiekis tabako kontrabandos į Lietuvą buvo gabenamas būtent iš Rusijos - gerokai daugiau negu iš kitų kaimyninių šalių. ${ }^{37} \mathrm{O}$ alkoholio kontrabandos tendencijos tuo pačiu periodu yra labai nepastovios, tačiau pastebima, kad nèra tokio ryškaus nelegalaus gabenimo masto iš Rusijos kaip tabako kontrabandos atveju. ${ }^{38}$

Dar viena svarbi migracijos procesų dalis, kurią galètu paveikti vizų panaikinimas tarp Europos Sąjungos ir Rusijos - prieglobsčio sistema ir jo srautu

\footnotetext{
${ }^{33}$ Interviu su Migracijos departamento prie Vidaus reikalų ministerijos Užsieniečių reikalų skyriaus vedeju p. Antanu Turčinu, $2011 \mathrm{~m}$. vasario $7 \mathrm{~d}$.

${ }^{34}$ Valstybès sienos apsaugos tarnyba prie Lietuvos Respublikos vidaus reikalų ministerijos, Užfiksuoti valstybès sienos pažeidimai, Vilnius, 2010, <http://www.pasienis.lt/lit/Uzfiksuoti_valstybes_sienos_pazeidimai/142/1>, 29012011.

${ }^{35}$ Valstybès sienos apsaugos tarnyba prie Lietuvos Respublikos vidaus reikalų ministerijos, Lietuvos pasienyje sulaikyti j̇tariamai ieškoti asmenys, Vilnius, 2010, <http://www.pasienis.lt/lit/Lietuvos_pasienyje_sulaikyti_itariamai_i/146/>, 29012011.

${ }^{36}$ Interviu su p. Alvydu Pumpučiu (išnaša 31).

${ }^{37}$ Valstybès sienos apsaugos tarnyba prie Lietuvos Respublikos vidaus reikalų ministerijos, Lietuvos pasienyje sulaikyta tabako kontrabanda, Vilnius, 2010, <http://www.pasienis.lt/lit/Lietuvos_pasienyje_sulaikyta_tabako_gami/140>, 29012011.

${ }^{38}$ Valstybès sienos apsaugos tarnyba prie Lietuvos Respublikos vidaus reikalų ministerijos, Sulaikyta alkoholio kontrabanda, Vilnius, 2010, <http://www.pasienis.lt/lit/IMG/139>, 29012011.
} 
svyravimai. Rusijos piliečiai sudaro didžiausią prieglobsčio prašytojų dalį Lietuvoje: 1997-2004 m. laikotarpiu jie kasmet vidutiniškai sudarydavo net 60 proc. visų prieglobsčio prašytojų, o 2005-2009 m. šis skaičius išaugo iki 74 proc. Analizuojant naujausius metinius duomenis, pažymètina, kad 2009 m. šis skaičius tradiciškai sudare didžiausią prieglobsčio prašytojų dalị (54 proc.), o daugiausia tokių prašymų pateike čečènų tautybès piliečiai (tai sudare apie 48 proc. visų pateiktų prašymų ir 88 proc. Rusijos piliečių prašymu), tačiau, palyginti su $2008 \mathrm{~m}$. duomenimis, bendras prašymų dèl prieglobsčio suteikimo skaičius sumažejo. ${ }^{39}$

Duomenys, susiję su Rusijos piliečių prašymais dèl prieglobsčio suteikimo, pateiktais visos Europos Sąungos ir kitų industrializuotų pasaulio valstybių mastu, rodo, kad tokių prašymų srautai 2009 m. sumažëjo, tačiau ši tendencija vertintina atsargiai, mat išryškëjo tik pastaraisiais metais, o kai kuriose Sajungos šalyse, ypač neturinčiose Europos Sąjungos išorinių sienų ar prisijungusiose prie Šengeno erdvès (pvz., Belgijoje, Vokietijoje, Olandijoje, Švedijoje, Liuksemburge, Austrijoje), šie srautai netgi padidejo. ${ }^{40}$

Bevizio režimo įvedimas galimai padidintų Rusijos piliečiu paskatas kuo ilgiau pasilikti Europos Sąungos teritorijoje, tikintis igyti pabègèlio statusą. Oficiali statistika rodo, kad 1997-2004 m. Lietuvoje pabègèlio statusas buvo suteiktas šešiolikai Rusijos piliečiu, o tai kasmet sudare vidutiniškai 20 proc. viso skaičiaus tų, kuriems suteiktas pabejgelio statusas. ${ }^{41}$ 2005-2009 m. šio statuso suteikimo mastai išaugo daugiau nei du kartus: šiuo laikotarpiu iš viso 37 Rusijos piliečiai pripažinti pabègeliais, o tai sudare didžiausią bendro pabègelių skaičiaus dali (net 60 proc.). ${ }^{42}$ Tikètina, kad bevizio režimo ịvedimas galetų paskatinti prieglobsčio prašymų mastų didējimą, nes, netgi esant dabartiniam vizų režimui, Rusijos piliečiai sudaro didžiausią prieglobsčio prašytojų dalį.

Atsižvelgiant ị migracijos bei prieglobsčio prašymo tendencijas, Migracijos departamento prognozes ir vertinant vizų panaikinimo tarp Europos Sajungos ir Rusijos padarinius Lietuvos nelegalios migracijos valdymo bei prieglobsčio prašymu priemimo sistemoms, galima teigti, kad nelegalių migrantų bei prieglobsčio prašytojų skaičiaus padidejjimas galimai padidintų šiose sistemose dirbančių tarnautojų darbo krūvius. Taip pat dideja rizika, kad Lietuva pagal Dublino II reglamentą turès prisiimti atsakomybę už kitose Europos Sąjungos valstybèse narèse pateiktus

\footnotetext{
${ }^{39}$ Interviu su p. Antanu Turčinu, $2011 \mathrm{~m}$. sausio 27 d. (30 išnaša).

${ }^{40}$ Ten pat.

${ }^{41} 2004$ m. Migracijos metraštis, (27 išnaša), p. 69.

422009 m. Migracijos metraštis, (28 išnaša), p. 85.
} 
prieglobsčio prašymus ${ }^{43}$ bei perimti Rusijos prieglobsčio prašytojus, kurie yra kirtę Lietuvos sieną ir patekę ì kitas Sąjungos šalis. ${ }^{44}$ Tokiu atveju būtų susiduriama su žmogiškųjų išteklių didinimo būtinybe, lydima papildomų finansinių išlaidų, kurios bus aptartos vèliau. ${ }^{45}$

\subsection{Bevizio režimo poveikis valstybès sienos apsaugos ir muitinès sistemoms}

Galimas vizų panaikinimas turètų poveikį Lietuvos sienos apsaugos ir LRM sistemoms. Vienas iš argumentų derybose dèl vizų panaikinimo ar galimų finansinių sąnaudų padengimo iš ES lěšų - Lietuvos atsakomybè už dalį Europos Sąjungos išorinès sienos. Atsižvelgiant ị tai, bevizio režimo įvedimas turètų reikšmingą ịtaką Valstybès sienos apsaugos tarnybos, atliekančios su sienos apsauga, keleivių ir transporto priemonių kontrole, valstybine migracijos procesų kontrole, pabėgèliu registravimo klausimais susijusias funkcijas, ir muitinès, atliekančios keleivių, pasienio zonos gyventojų ir transporto priemonių ir jų gabenamų daiktų (prekių) kontrolę, veiklos organizavimui. ${ }^{46}$

İvedus bevizị režimą pastebimai išaugtų per Lietuvos kontroliuojamą Europos Sąjungos išorès sieną vykstančių keleivių, transporto bei prekių (daiktų) srautai. Panaikinus vizu režimą tikètina, padidès šios kategorijos keliautojų skaičius, nes nereikès mokèti už vizas, todèl į šią veiklą gales ịsitraukti didesnis skaičius mažas pajamas turinčių asmenų, ypač pasienio gyventojų, kurių kelionès tikslas būtų gauti pajamų iš nelegalios prekybos. Dèl skirtingos šalių akcizų politikos ir egzistuojančio prekių kainų skirtumo dides nelegalios prekybos legaliai įvežta produkcija rizika. Didejjant srautams didès ir kontrabandos būdu ịvežamų prekių patekimo ị Lietuvą rizika. Dèl to Lietuvos biudžetas patirs nemažų nuostolių. Vien $2010 \mathrm{~m}$. muitinès užkardyta žala dẻl neteiseto rusiškų cigarečiu įvežimo sieke $45 \mathrm{mln}$. Lt., todèl, kol yra tokia skirtinga Rusijos ir ES šalių akcizų politika, panaikinus vizas padaugès ekonominio pobūdžio pažeidimų, susijusių su prekių kontrabanda, grèsmé, tačiau

\footnotetext{
${ }^{43} 2009$ m. Migracijos departamentas prième 222 sprendimus prisiimti atsakomybę už kitose ES šalyse pateiktų prieglobsčio prašymų nagrinëjimą (pagal 2003 m. vasario 18 d. Tarybos reglamentą Nr. 343/2003). Beveik pusè šių sprendimų (107) priimta dẻl Rusijos Federacijos piliečių prašymų.

${ }^{44}$ Interviu su p. Antanu Turčinu, $2011 \mathrm{~m}$. sausio 27 d. (30 išnaša).

45 Ten pat.

${ }^{46}$ Valstybès sienos apsaugos tarnybos prie Lietuvos Respublikos vidaus reikalų ministerijos nuostatai, patvirtinti Lietuvos Respublikos Vyriausybes 2001 m. vasario 22 d. nutarimu Nr. 194, <http://www3.lrs.lt/pls/ inter3/dokpaieska.showdoc_l?p_id=163112>, 28012011.
} 
sunku tiksliai prognozuoti srautų augimo mastus. ${ }^{47}$ Atsižvelgiant į minètą srautų ir sienos kirtimo mastu augimą, padidëja kontrolès apkrova ir tikrinimų trukmé Lietuvos pasienyje, mat panaikinamas pirmasis Integruoto sienų valdymo modelio filtras, apimantis sienos politikos vykdymą trečiosiose šalyse, tranzitinèse šalyse ir kilmès šalyse, t.y., nebelieka keleivių kontrolès funkcijų igyvendinimo konsulinèse istaigose. ${ }^{48}$

Siekiant efektyviai suvaldyti tokią galimą išaugsiančių keleivių, transporto, daiktų (prekių) srautų bei patikros apkrovų pasienyje problemą, pastangas reikètų nukreipti į žmogiškųjų ir finansinių išteklių, infrastruktūros bei modernių keleivių, transporto, daiktų (prekiu) tikrinimo priemonių pletrą.

Pastaruoju metu kai kuriuose pasienio kontroles punktuose faktinis pralaidumas viršija projektini, o vizų schemos naikinimo atveju tokios tendencijos, tikètina, sustiprès, todèl planuojama darbui šiuose punktuose skirti maksimalu skaičių tikrinimą atliekančių tarnybų pareigūnų. Tai reiškia, kad vien Valstybès sienos apsaugos tarnyboje reiketų maždaug 215 papildomų pareigybių. ${ }^{49}$ Reikia pažymèti, kad tikslaus žmogiškujjų išteklių padidejjimo apskaičiuoti kol kas neįmanoma, mat trūksta duomenų, kiek ir kuriuose punktuose reikès didinti muitinés pareigūnų skaičių. ${ }^{50}$

Svarbu pabrěžti, kad Specialiosios tranzito schemos, kaip Išorès sienu fondo (ISF) dalies, finansavimui Europos Komisija numate per 2007-2013 m. laikotarpị skirti $108 \mathrm{mln}$. eurų, šias lěšas panaudojant tranzitą tarp Kaliningrado ir kitų Rusijos dalių reglamentuojančiai Europos Sąjungos acquis ịgyvendinti. ${ }^{51}$ 2011-2013 m. pagal ISF metines programas Lietuvai dar skirta $48 \mathrm{mln}$. euru specialiosios Kaliningrado tranzito schemos funkcionavimui (po $16 \mathrm{mln}$. euru kasmet). Paskutiniams metams numatytų lešų ịsisavinimas numatytas iki 2015 m. birželio $30 \mathrm{~d}$. Pažymètina, kad greito bevizio režimo įvedimo atveju iškiltų papildomas klausimas dẻl likusių numatytų lěšų panaudojimo. Kai kurie iš šių ES lěšų finansuojami projektai yra tęstiniai, tad baigtinio jų igyvendinimo nebuvimas reikštų bereikalingas išlaidas. ${ }^{52}$

\footnotetext{
${ }^{47}$ Interviu su Valstybes sienos apsaugos tarnybos prie Lietuvos Respublikos vidaus reikalų ministerijos Štabo Veiklos organizavimo valdybos Pasienio kontroles skyriaus viršininku p. Audriumi Pauliukevičiumi, $2011 \mathrm{~m}$. vasario $10 \mathrm{~d}$.

${ }^{48}$ Interviu su p. Alvydu Pumpučiu (31 išnaša).

${ }^{49}$ Interviu su p. Audriumi Pauliukevičiumi (47 išnaša).

${ }^{50}$ Viename kontrolés punkte turètų dirbti 21 muitinès pareigūnas, siekiant užtikrinti efektyvią asmenų ir transporto kontrolę. Interviu su Muitinés departamento prie Lietuvos Respublikos finansų ministerijos generalinio direktoriaus pavaduotoju p. Jonu Miškiniu, $2011 \mathrm{~m}$. vasario $11 \mathrm{~d}$.

${ }^{51}$ Centriné projektų valdymo agentūra, Specialioji tranzito schema 2007-2013 m., 2011, <http://www.cpva.lt/ specialioji-tranzito-schema/>, 28012011.

${ }^{52}$ Lietuvos Respublikos vidaus reikalų ministerija, Vizu režimo tarp ES ir Rusijos panaikinimo poveikio Lietuvai vertinimas, $2010 \mathrm{~m}$. lapkritis.
} 
Tačiau būtina atkreipti dèmesị i tai, kad Bendrijos muitinès kodekse asmenų gabenamoms prekèms nereglamentuota ir netaikoma tranzito procedūra. Pagal galiojančius teisès aktus asmenys, vykstantys iš/į Kaliningrado sriți, su savimi gabenamus daiktus turètų deklaruoti išleidimo ị laisvą apyvartą procedūrai, sumokant teisès aktuose numatytus mokesčius. Tikètina, kad tai netenkintų Rusijos pusès, todèl šis klausimas turi būti aptartas ir reglamentuotas derybų dèl bevizio režimo metu. ${ }^{53}$

Dar vienas svarbus bevizio režimo įvedimo poveikio aspektas valstybès sienos apsaugos ir LRM sistemoms apima Lietuvos pasienio kontroles punktu modernizaciją. Aktualia problema tampa punktų bei jų prieigos infrastruktūros pertvarkymas ir projektinio bei praktinio pralaidumo pajegumų didinimas. ${ }^{54} \mathrm{~Pa}$ sienio kontrolès punktų pralaidumo problemos spendimui svarbūs keli aspektai. Reikalingos infrastruktūros įrengimas didinant materialiuosius pajëgumus (pvz., įrengiant aikšteles ar plečiant eismo juostų pasienio kontrolès punktų teritorijose skaičiu) padètų užtikrinti geresnes laukimo eilëje sąlygas Lietuvos Respublikos pasienyje. Taip pat svarbu užtikrinti LRM bei pasienio tarnybos sąveiką, kontrolès organizavimo principus. Pasienio kontrolés punktų pralaidumo laipsni galètų padidinti atitinkamai modernizuota Rusijos pasienio punktų infrastruktūra. ${ }^{55}$

\subsection{Bevizio režimo poveikis vidaus saugumo užtikrinimui}

Lietuvos vidaus saugumui bevizis režimas turètų neigiamą įtaką ir būtų susijęs su keliais iššūkiais: tai bendras nusikalstamumo didëjimas, organizuoto nusikalstamumo grupuočių veiklos intensyvëjimas, terorizmo bei prekybos žmonèmis grèsmių augimas. Dèl ypatingos Lietuvos geografinès padèties šaliai iškiltų didesnis pavojus tapti narkotiku gabenimo tranzitine šalimi (i Kaliningradą iš visų likusių Rusijos Federacijos dalių). ${ }^{56}$ Tokius vertinimus sustiprina ir Europolo atliktoje Rusijos organizuoto nusikalstamumo grèsmių vertinimo metodologijoje (ROCTA) pateikti duomenys, žymintys Rusijos piliečių nusikalstamų veikų slinktį nuo smurtinių prie finansinių nusikaltimų, ir traktuojantys šios kaimyninès šalies organizuoto nusikalstamumo grupuotes, kaip darančias didelę netiesioginę ịtaką

\footnotetext{
${ }^{53}$ Interviu su Muitinès departamento prie Lietuvos Respublikos finansų ministerijos generalinio direktoriaus pavaduotoju p. Jonu Miškiniu, 2011 m. vasario 19 d.

${ }^{54}$ Interviu su p. Alvydu Pumpučiu (31 išnaša).

${ }^{55}$ Kaip pavyzdi galima pateikti Panemunès-Sovetsko ir Ramoniškių-Pagraničnij punktus, kuriuose Rusijos pusės infrastruktūra neatitinka lietuviškosios, egzistuoja modernizavimo lygio nesutapimų. Interviu su Pasienio kontrolés punktų direkcijos prie Lietuvos Respublikos susisiekimo ministerijos Statybų skyriaus vedeju p. Algirdu Blaškevičiumi, $2011 \mathrm{~m}$. sausio $27 \mathrm{~d}$.

${ }^{56}$ Interviu su Policijos departamento prie Lietuvos Respublikos vidaus reikalų ministerijos Tarptautinio bendradarbiavimo valdybos viršininke p. Audrone Sviklaite, $2011 \mathrm{~m}$. sausio $31 \mathrm{~d}$.
} 
saugumo užtikrinimui Europos Sąjungos mastu. ${ }^{57}$ Kartu reikia pažymèti ir itin svarbų aspektą Lietuvai, jog policija iš VSD neseniai perèmé kovos su terorizmu funkcijas ir kol kas tam nebuvo skirti papildomi ištekliai. ${ }^{58}$

Anksčiau aptarti augsiantys migracijos mastai gali prisidèti prie galimo nusikalstamumo didejjimo: tarp ikiteisminèse įstaigose užregistruotų užsieniečių, kaltinamų nusikalstamos veikos padarymu, jau dabar didžiausią dalị (daugiau nei $25 \%$ visų įtariamųjų) sudaro būtent Rusijos piliečiai. ${ }^{59}$ Kalbant apie konkrečias nusikalstamas veikas, kurias padaro užsieniečiai, pažymėtina, kad dominuoja vagystès, kelių eismo taisyklių pažeidimai, įvairūs sukčiavimai, tačiau nemažą dalị sudaro sunkūs bei labai sunkūs nusikaltimai.

Atsižvelgiant ị ịvardytas grèsmes, bevizio režimo įvedimas turètų reikšmingos itakos kriminalinès bei viešosios policijos veiklos organizavimui, o tai pirmiausia būtų susiję su papildomų žmogiškųjų bei finansinių išteklių poreikiu. Viešosios policijos veiklos atžvilgiu vizų režimo panaikinimas reikštų policijos įstaigų migracijos padalinių pareigūnų, prevencijos padalinių tyrëjų (apylinkès inspektoriams) ir policijos patrulių darbo krūvio augimą, siekiant efektyviau sukontroliuoti Rusijos piliečių leistiną maksimalaus buvimo Lietuvoje laiką. Antra vertus, dẻl galimai padidesiančios nelegalios prekių apyvartos bei galimo nelegalaus darbo turetų padideti prevencijos padalinių, muitinés tyreju darbo apkrovos. Tuo pat metu kriminalines policijos organizavimas bevizio režimo įvedimo atveju turetų būti labiau sutelktas i galimų terorizmo grésmių neutralizavimą - tam taip pat reikètų papildomų žmogiškųjų bei technologinių išteklių. ${ }^{60}$ Remiantis preliminariais Policijos departamento duomenimis, vizų režimo panaikinimas pareikalautų 22 papildomų pareigybių kriminalinés policijos ir 28 pareigybių viešosios politikos adekvačiam veiklos organizavimui užtikrinti. ${ }^{61}$

Dar vienas svarbus policijos ir LRM veiklos organizavimo aspektas - informacinių technologijų pletros, palaikymo ir tobulinimo poreikis. Bevizio režimo ivedimo atveju padidejus keleivių, transporto priemonių ir gabenamų daiktų (prekių) srautams, technologinių priemonių naujinimas (pirmiausia Policijos informacinès sistemos POLIS tobulinimas) būtų ypač aktualus dalykas, siekiant efektyviau kontroliuoti Rusijos piliečių atvykimą bei buvimo Lietuvoje laiką. Be to, būtina vystyti policijos ir muitinès informacinių sistemų suderinamumą informacijos mainams.

\footnotetext{
57 Ten pat.

${ }^{58}$ Interviu su Policijos departamento prie Lietuvos Respublikos vidaus reikalų ministerijos Tarptautinio bendradarbiavimo valdybos viršininke p. Audrone Sviklaite, $2011 \mathrm{~m}$. vasario $6 \mathrm{~d}$.

${ }^{59}$ Interviu su p. Audrone Sviklaite, $2011 \mathrm{~m}$. sausio $31 \mathrm{~d}$. (56 išnaša).

${ }^{60}$ Ten pat.

${ }^{61}$ Interviu su p. Aleksandr Valentij, 2011 m. vasario 9 d. (29 išnaša).
} 
Vidaus saugumui užtikrinti įvedus bevizį režimą reikalingas kokybiškai naujas teisinis pagrindas, kuris padètų efektyviau bendradarbiauti Lietuvos Respublikos ir Rusijos pareigūnams. Reikia pažymèti, kad iki šiol nèra sudaryta dvišalè sutartis su Rusija dèl kovos su organizuotu nusikalstamumu, kurios projektą Lietuva pateikè dar 2001 m. Pažymètina, kad tokia sutartis užtikrintų efektyvesnį bei paprastesni keitimąsi ịvairaus pobūdžio informacija. Šios sutarties pagrindu ne mažiau svarbu sudaryti žemesnio lygmens (tarpžinybinę) sutartį Vidaus reikalų, Finansų ministerijų lygiu, kuri leistų tiesiogiai bendradarbiauti su atitinkamomis Kaliningrado srities teisésaugos ir LRM institucijomis bei padetų dorotis su padidesiančiais migracijos, nusikalstamumo, transporto priemonių ir gabenamų daiktų (prekių) srautais po bevizio režimo įvedimo. Be to, analizuojant Europos Sąjungos ir Rusijos teisèsaugos bendradarbiavimo ypatybes, verta pažymèti, kad taip pat nèra pasirašyta Europos policijos biuro (Europolo) bei atitinkamų Rusijos institucijų sutartis, kuri leistų vykdyti bendrus tyrimus, sudarytų sąlygas keistis asmens duomenimis, kartu užtikrinant tokių duomenų apsaugos didinimą Rusijoje. ${ }^{62}$

\section{Bendra finansinè našta Lietuvai dèl bevizio režimo ịvedimo}

Analizuojant Europos Sąjungos - Rusijos bevizio režimo pasekmes Lietuvai, reikia apskaičiuoti bendrą finansinę naštą, galimai teksiančią šaliai. Skaičiavimuose remiamasi tyrime minimų institucijų pateiktais bei tyrimo metu kritiškai įvertintais duomenimis. Kartu reikia pažymèti, kad skaičiavimų rezultatai yra preliminarūs, kadangi, kaip jau buvo minèta, keblu tiksliai prognozuoti daugelio veiksniu poveikị ir tikslias išlaidas, susijusias su bevizio režimo įvedimu. Finansinių sąnaudu analizę vertètų pradèti nuo piniginių išteklių, kurių Lietuva netektų, jeigu būtų panaikinta dabar veikianti vizų schema, įverčio.

Išores sienų fondui priklausanti Specialioji tranzito schema, kurios finansavimui 2007-2013 m. finansinëje perspektyvoje numatyta $108 \mathrm{mln}$. eurų, įvedus bevizị režimą nebetektų prasmès, taigi vidutiniškai kasmet Lietuva prarastų apie 55,2 mln. litu pagal šią schemą teikiamos ES suprogramuotos paramos. İvedus bevizį režimą Lietuva prarastų galimybę i v valstybès biudžetą surinkti mokestị už vizas, kuris šiuo metu sudaro 35 eurus už vieną vizą. 2008-2009 m. Rusijos piliečiams vidutiniškai išduotos 122062 vizos, taigi kasmet tai sudaro apie 14,8

\footnotetext{
${ }^{62}$ Interviu su Muitinès departamento prie Lietuvos Respublikos finansų ministerijos generalinio direktoriaus pavaduotoju p. Jonu Miškiniu, $2011 \mathrm{~m}$. sausio $26 \mathrm{~d}$.
} 
mln. litų papildomų pajamų. ${ }^{63} \mathrm{Ne}$ mažiau reikšmingos išlaidos, susijusios su Specialiosios tranzito schemos įrangos, įsigytos už ES fondų lěšas, palaikymu ir atnaujinimu. Kaip žinia, minètosios schemos veikimo panaikinimas lemtų tokios įrangos išlaikymo finansinių įsipareigojimų perkèlimą Lietuvai. ${ }^{64}$ Nutraukus šios schemos funkcionavimą Lietuva prarastų ES lěšas, kurios buvo numatytos pagal Lietuvos stojimo į ES sutarties penktą protokolą. ${ }^{65}$ Pagal specialiąją Kaliningrado tranzito schemą yra įdarbinti 102 Užsienio reikalų ministerijos sistemoje dirbantys konsuliniai darbuotojai, kurių finansavimas $2010 \mathrm{~m}$. sudare 7,6 milijono litų, ir 184 VSAT darbuotojai, kuriems skiriamos lěšos iš minetos schemos sudare 7,2 milijono litų. Dar beveik 2,3 mln. litų atiteko papildomoms VSAT administracinèms, asmenų grąžinimo bei technikos eksploatacijos išlaidoms. İsigaliojus beviziam režimui, Lietuvos biudžetas ne tik netektų minètų lěšų iš ES, bet ir turètų atleisti dalį URM (apie 70 asmenų) bei VSAT darbuotojų, kurių atlyginimai buvo finansuojami tik iš specialiosios Kaliningrado tranzito schemos. Jei bevizis režimas ìsigaliotų 2013 m., Lietuva, panaikinus minètą schemą, prarastų vienerių metų sumą - 16 milijonų eurų, mat lešų 2013 metams suplanavimas ir patvirtinimas EK vyksta iki $2012 \mathrm{~m}$. lapkričio $1 \mathrm{~d} .^{66}$

Bevizio režimo įvedimo atveju, kaip minèta, nebeliktų keleivių kontrolès funkcijų igyvendinimo konsulinèse įstaigose, o dalis šių funkcijų būtų perkelta ì pasienį. Padidèsiantiems keleivių srautams suvaldyti, kontrolès efektyvumui bei adekvačiai patikros spartai užtikrinti reikès daugiau žmogiškųjų išteklių, kuriems reikès tam tikrų finansinių sąnaudų. Apytiksliai tai sudarytų 10750000 litų papildomų išlaidų per metus. ${ }^{67}$

Itin svarbi tampa pasienio kontroles punktų pralaidumo problema, kurios sprendimas priklauso nuo šių punktų infrastruktūros pertvarkos Rusijos pasienyje. Pasienyje galimai tektų įrengti transporto priemonių laukimo aikšteles. Nors dauguma pasienio kontroles punktų pastatyti santykinai neseniai, bevizio režimo ivedimas gali pareikalauti infrastruktūros modernizacijos pasienyje su Kaliningrado sritimi. Gali atsirasti poreikis plèsti transporto priemonių laukimo aikštelių skaičių

\footnotetext{
${ }^{63}$ Interviu su Lietuvos Respublikos užsienio reikalų ministerijos Konsulinio departamento Šengeno skyriaus vedëju p. Rimgaudu Lošiu, $2011 \mathrm{~m}$. sausio $24 \mathrm{~d}$.

${ }^{64}$ Interviu su Lietuvos Respublikos vidaus reikalu ministerijos Tarptautinio bendradarbiavimo departamento direktoriumi p. Olegu Skinderskiu, $2011 \mathrm{~m}$. sausio $28 \mathrm{~d}$.

${ }^{65}$ Protokolas Nr. 5 „Dẻl asmenų sausumos tranzito tarp Kaliningrado srities ir kitų Rusijos Federacijos dalių“, <http://eur-lex.europa.eu/LexUriServ/LexUriServ.do?uri=CELEX:12003T/PRO/05:LT:HTML>, 07022011 ${ }^{66}$ Interviu su Lietuvos Respublikos vidaus reikalų ministerijos ES paramos administravimo skyriaus vedeja p. Daiva Racevičiene, $2011 \mathrm{~m}$. vasario $7 \mathrm{~d}$.

${ }^{67}$ Interviu su p. Audriumi Pauliukevičiumi (47 išnaša).
} 
ar plotą ir atnaujinti infrastruktūros funkcijas aptarnaujančią IT bazę ${ }^{68}$ Panemunès pasienio kontroles punkto lengvųjų automobilių ir krovininio transporto laukimo aikštelių su papildoma infrastruktūra projektavimas ir įrengimas sudarytų apie 4 mln. litų, Kybartų - apie 3 mln. litų, Ramoniškių punktas būtų modernizuojamas realizuojant antraji šio punkto statybos etapą, t.y. sudarant sąlygas ir krovininio transporto judejjimui, įrengiant papildomas eismo juostas su lydinčia infrastruktūra. Tai sudarytų apie $6 \mathrm{mln}$. litų. Prie punkto statomos aikštelès su infrastruktūra sąnaudos siekia beveik $4 \mathrm{mln}$. litų. Reikia pabrěžti, jog čia pateikti preliminarūs duomenys, kadangi tikslius skaičius galima nustatyti tik atlikus realius projektavimo darbus. ${ }^{69}$ Be to, pažymima, kad del infrastruktūros ir higieninès situacijos pagerinimo Panemune-Sovietskas punkte reikalingas naujas tiltas per Nemuną ir su juo susijusi infrastruktūra. Susisiekimo infrastruktūros (kelio tiesimo) sąnaudos siekiant pagerinti Lietuvos-Rusijos sienos kirtimą ties Panemune-Sovietsku gali sudaryti apie 45 milijonus litų. Visgi tikimasi apie 35 milijonus litu gauti iš Europos kaimynystes ir partnerystés priemonés, Lietuvos, Lenkijos ir Rusijos bendradarbiavimo per sieną programos, jei bus gautas Lenkijos ir Europos Komisijos pritarimas, kadangi Rusija, kuri pagal susitarimą būtų finansiškai atsakinga už būsimo tilto per Nemuną statybą, pritaria lěšu panaudojimui iš minètos programos. ${ }^{70}$

Bevizio režimo įvedimas pareikalautų pasienio kontrolès punktų infrastruktūros plètros ir tikrinimo ịrangos atnaujinimo. Būtinomis ar trūkstamomis techninemis prekių ir daiktų kontrolès priemonemis reikètų aprūpinti muitinès postus, besiribojančius su išorinemis Europos Sąungos sienomis. Tai yra Kauno teritorinès muitinès Kybartų ir Ramoniškių, taip pat Klaipèdos teritorinès muitinès Panemunès bei Nidos kelio postai. Pažymètina, kad preliminari vieno tokio posto standartinès įrangos verte sudaro vidutiniškai 600 tūkst. litų, taigi tokio muitinių postų modernizavimo ir technologinio adekvatumo užtikrinimo sąnaudos siektų apie 2,4 mln. litų. Dar vienas muitinés punktų veiklos sustiprinimo aspektas - rentgeno kontrolès sistemos transporto priemonèms ir kroviniams tikrinti įsigijimas. ${ }^{71}$ Dvi stacionarios/kilnojamos sistemos Panemunes ir Kybartu postuose kainuotu apie 14 milijonų litų, bet tai, esant teigiamam paraiškos vertintojų sprendimui, būtų finansuojama iš Europos kaimynystès ir partnerystès priemonès, Lietuvos, Lenkijos ir Rusijos bendradarbiavimo per sieną programos rémuose jau $2011 \mathrm{~m}$.

\footnotetext{
${ }^{68}$ Interviu su Pasienio kontroles punktų direkcijos prie Lietuvos Respublikos susisiekimo ministerijos Statybų skyriaus vedëju p. Algirdu Blaškevičiumi, $2011 \mathrm{~m}$. vasario $7 \mathrm{~d}$.

${ }^{69}$ Interviu su Pasienio kontroles punktų direkcijos prie Lietuvos Respublikos susisiekimo ministerijos Statybų skyriaus vedëju p. Algirdu Blaškevičiumi, $2011 \mathrm{~m}$. vasario $10 \mathrm{~d}$.

${ }^{70}$ Interviu su Kelių ir civilinès aviacijos departamento prie Lietuvos Respublikos susisiekimo ministerijos direktoriumi p. Šarūnu Baubliu, $2011 \mathrm{~m}$. vasario $10 \mathrm{~d}$.

${ }^{71}$ Interviu su p. Jonu Miškiniu. 2011 m. vasario 11 d. (50 išnaša).
} 
pirmą pusmetị. Vèliau rentgeno kontrolès sistemomis planuojama aprūpinti likusius LRM postus keturiomis sistemomis ( 2 - muitinès kelio postuose, 2 - muitinés geležinkelio postuose), kurių kaina siektų apie 50 milijonų litų. Pažymètina, kad vienos tokios sistemos metinès eksploatacinès išlaidos siekia apie $200000 \mathrm{Lt}^{72}$

Bevizio režimo tarp Europos Sąjungos bei Rusijos įvedimas galimai pareikalautų didesnio žmogiškųjų išteklių skaičiaus nelegalios migracijos bei prieglobsčio valdymo srityje. Pasak Valstybès sienos apsaugos tarnybos specialistų, būtinos didesnès pajègos, reikalingos kontroliuoti bevizio režimo laikymuisi šalies viduje, ypač siekiant grą̧̌̌inti nelegalius migrantus ar kitus ịstatymui nepaklususius Rusijos Federacijos piliečius atgal į tẻvynę. Tokiu atveju prireiktų didinti Europos grąžinimo fondo skiriamą paramą ${ }^{73}$ Svarbu pažymèti, kad Lietuvai $2008-2013$ m. iš šio fondo numatyta skirti beveik $5 \mathrm{mln}$. eurų paramos ${ }^{74}$ taigi spejjama, jog ši parama turètų padidèti bent du kartus - tai turètų sudaryti apie $10 \mathrm{mln}$. eurų ${ }^{75}$

2010 metais prieglobsčio prašěsi 113 Rusijos piliečiu, prieglobstis suteiktas 68 asmenims. ${ }^{76}$ Vieno prieglobsčio prašymo nagrinëjimo išlaidas sudaro apie 3000 litų, o asmens, gavusio prieglobstị, integracija kainuoja apie 1500 litų. Susumavus paaiškejja, kad $2010 \mathrm{~m}$. tokios išlaidos siekè apie 340000 litų, o integracijos sąnaudos buvo apie 100000 litų. Nors Migracijos departamentas prognozių nepateikè, tačiau, remiantis Policijos departamento prognozemis apie migrantų skaičiaus padidejjimą ir siejant jị su proporcingu prieglobsčio prašymų išaugimu, galima prognozuoti, kad bevizio režimo ịvedimas sudarytų maždaug vieną milijoną litų, kuriuos reikètų skaičiuoti kaip išlaidas prieglobsčio teikimo sistemai. Be to, pažymètina, kad viena užsieniečio išlaikymo diena Pabradès Užsieniečių registracijos centre kainuoja 50 litų. 2010 metais centre buvo 69 Rusijos Federacijos piliečiai. Bendras jų buvimo dienų skaičius - 5634 dienos, taigi bendra išlaidų suma sieke beveik 282000 litų.

Remiantis Policijos departamento prognozėmis, bevizio režimo sąlygomis siekiant igyvendinti policijai pavestas funkcijas, ${ }^{77}$ atsiras papildomų žmogiškujjų ir finansinių išteklių poreikis. Pažymètina, kad naujų kriminalinès policijos pareigybių išlaikymo išlaidos per metus sudaro 1026200 litų. Naujai ịsteigtų pareigybių

\footnotetext{
${ }^{72}$ Interviu su Muitinès departamento Statistikos analizès skyriaus viršininko pavaduotoju p. Šarūnu Ramanausku, $2011 \mathrm{~m}$. vasario $10 \mathrm{~d}$.

${ }^{73}$ Interviu su p. Alvydu Pumpučiu (31 išnaša).

${ }^{74}$ Centriné projektų valdymo agentūra, Europos grą̌̌inimo fondas 2008-2013 m., 2011, <http://www.cpva.lt/ europos-grazinimo-fondas/>, 31012011.

${ }^{75}$ Interviu su p. Audriumi Pauliukevičiumi ( 47 išnaša).

${ }^{76}$ Interviu su p. Antanu Turčinu, $2011 \mathrm{~m}$. vasario 7 d. (33 išnaša).

77 T.y. užkardyti, atskleisti ir ištirti nusikalstamas veikas ir kitus teisès pažeidimus ekonomikai, verslo tvarkai ir finansams, sustiprinti akcizais apmokestinamų ir kitų prekių nelegalios apyvartos kontrolę teritorinėse policijos įstaigose, besiribojančiose su Rusijos siena.
} 
veiklai užtikrinti būtinos papildomos išlaidos: pareigūnų uniforminei aprangai - 78 284 litų; pareigūnų darbo vietoms įrengti - 132000 litų; tarnybiniam transportui (papildomai 4 automobiliams) įsigyti ir išlaikyti - 440000 litų.

Vizų režimo panaikinimas Lietuvos policijai svarbus finansine prasme. Nutraukus specialiosios tranzito schemos vykdymą netenkama finansinès paramos iš ISF, o tai, skaidant lěšas, policijos finansavimą kasmet vidutiniškai sumažintų $10 \mathrm{mln}$. litų. ${ }^{78}$ Tokiu atveju Lietuvai neteks vykdyti šios programos priemonių, tačiau nereikia pamiršti lěšų, skirtų ịsigytos įrangos eksploatacijai ir palaikymui, poreikio. ${ }^{79}$ Atsižvelgiant į ịvardytą darbo krūvio padidëjimą, minètos finansinès paramos netekimas gali turèti neigiamos įtakos saugumo grèsmių valdymui vizų panaikinimo Rusijai kontekste.

Remiantis preliminariais Viešosios policijos valdybos skaičiavimais, viešajam saugumui garantuoti taip pat reikètų papildomų žmogiškųjų išteklių. Jų išlaikymo sąnaudos per metus - 1213950 litų. Naujai įsteigtų pareigybių veiklai užtikrinti būtinos papildomos išlaidos pareigūnų uniforminei aprangai - 118384 litų, darbo vietoms įrengti - 168000 litų, tarnybiniam transportui (papildomai 15 automobilių) įsigyti ir išlaikyti - 660000 litų. Prie IT sektoriaus techninès bazès atnaujinimo išlaidų (POLIS sistemos atnaujinimas kainuoja 500000 litų) reikia priskirti darbus, susijusius su rusų kalbos transliteracijos naudojimu Lietuvos policijos registruose ir informacinèse sistemose, kuriose kaupiami demografiniai duomenys. Tokių atnaujinimų sąmata gali būti nuo 100 tūkst. litų iki $1 \mathrm{mln}$. litų. Jei papildomai reiketų specializuotų skaitytuvų, sąmata išaugtų iki 3-4 mln. litų. Prie technologinio policijos veiklos patobulinimo galima priskirti būtinumą įsigyti biologinio, cheminio ir radioaktyvios taršos nustatymo įrenginius (5 vnt.), kaip prevencinio pobūdžio techninę priemonę, skirtą teroristinių išpuolių galimybèms užkirsti. Tokia įranga kainuotų apie 350000 litų, tačiau jos poreikį pagrindžia tai, kad Rusijai panaikinus vizų režimą, manoma, gali padidèti teroristinių išpuolių tikimybe Lietuvoje. ${ }^{80}$ Dar viena finansavimo didinimo poreikio sritis yra susijusi su rinktine „Aras“: grésmių likvidavimui užtikrinti rinktinei reikalinga technologinè įranga ir priemonès, kurios gali maksimaliai kainuoti maždaug 2361500 litų. Tokị lešų padidejjimą galima sieti ne tik su bevizio režimo įvedimu, bet ir su bendrais poreikiais kovoje su terorizmu perimant VSD funkcijų dali, jei joms vykdyti iš Lietuvos biudžeto nèra skiriamas papildomas finansavimas.

\footnotetext{
${ }^{78}$ Interviu su Policijos departamento prie Lietuvos Respublikos vidaus reikalų ministerijos tarptautinio bendradarbiavimo valdybos vyriausiuoju specialistu p. Aleksandr Valentij, $2011 \mathrm{~m}$. vasario 9 d. (29 išnaša). ${ }^{79} 2010$ m. šios eksploatacinés išlaidos sudare 1218000 Lt, tačiau prognozuojama, kad 2011 m. jos sumažès iki 1184000 Lt. Interviu su Policijos departamento prie Lietuvos Respublikos vidaus reikalų ministerijos tarptautinio bendradarbiavimo valdybos vyriausiuoju specialistu p. Aleksandr Valentij, $2011 \mathrm{~m}$. vasario $11 \mathrm{~d}$. ${ }^{80}$ Pagrindine tikètina problema - tai įvairaus tipo sprogmenų, įskaitant ir „nešvarias bombas“ su CBRN elementais, gabenimas, laikymas ir panaudojimas teroristiniams išpuoliams, taip pat tiketini ir plataus masto įkaitų pagrobimo atvejai. Interviu su p. Aleksandr Valentij, 2011 m. vasario 9 d. (29 išnaša).
} 
Remiantis preliminariais Muitinès departamento skaičiavimais, siekiant užtikrinti išaugsiančio vykstančių asmenų srauto muitinę kontrolę LRM postus pasienyje su Kaliningrado sritimi reikètų aprūpinti moderniomis rentgeno kontrolès sistemomis (toliau - RKS). Nauju RKS įdiegimą reiketų atlikti dviem etapais: pirmojo etapo metu issigyti 2 stacionarias/kilnojamas RKS (preliminari kaina - apie 14000000 litu), antrojo etapo metu issigyti dar 4 stacionarias RKS (po dvi kelio ir geležinkelio muitinés postams) Jų preliminari kaina - apie 40000000 litų. Vienos tokios RKS metinès eksploatacines išlaidos siekia apie 200000 litų, todell, atsižvelgiant ị įdiegtų RKS skaičių, eksploatacinių išlaidų suma gali svyruoti nuo 400000 iki 1200000 litų per metus. Muitinès kontrolei užtikrinti šalies viduje muitinès mobiliosios grupès (toliau - MMG) turi būti aprūpintos modernia muitinio tikrinimo įranga, taip pat reiketų papildomų žmogiškujjų išteklių bei transporto priemonių ${ }^{81}$

Apibendrinant atliktą preliminarios bendros finansinès naštos Lietuvai analizę, Europos Sąjungos - Rusijos bevizio režimo įvedimo sąnaudas galima skirstyti į dvi dalis. Viena dalis susijusi su patiriamais finansiniais nuostoliais dèl sumažejusio ES finansavimo, o pirmiausia - dèl paramos pagal Specialią̧ą tranzito schemą netekimo, taip pat dèl lěšų, gautų surinkus vizos mokesčius, praradimo. Šios rūšies bendrosios sąnaudos ${ }^{82}$ per metus sudarytų maždaug $70 \mathrm{mln}$. litų ir net galimai daugiau.$^{83}$ Antroji sąnaudų dalis apibūdintina kaip prognozuojamosios (žr. 1 lentelę).$^{84}$ Pastarosios sąnaudos gali būti tiek metinès, kurias sudaro papildomų pareigybių ir atitinkamos ịrangos išlaikymas, tiek papildomos „vienkartinès“, apimančios infrastruktūros ịrengimus, technikos pirkimą bei būsimus projektus. Gavus pageidautiną paramą (daugiausiai iš Europos kaimynystes ir partnerystès priemonès, Lietuvos, Lenkijos ir Rusijos bendradarbiavimo per sieną programos), tokių projektų sąnaudos sumažetų. Tyrime minètų institucijų atstovai nedetalizavo, kokie finansiniai šaltiniai galetų kompensuoti netenkamas lěšas ar išaugusias sąnaudas. Visgi, remiantis Policijos departamento duomenimis, tai galètų būti ES finansiniai mechanizmai. ${ }^{85}$

\footnotetext{
${ }^{81}$ Papildomų MMG pareigybių atlyginimų fondo išlaidos sudaro 658500 litų, papildomos išlaidos pareigūnų uniforminei aprangai - 60000 litų, naujų patrulinių ir kinologinei veiklai skirtų transporto priemonių įsigijimas - 850000 litų, modernios muitinio tikrinimo techninès įrangos įsigijimas - 1050000 litų.

${ }^{82}$ Metines pajamos pagal Specialiąją tranzito schemą bei surinkti mokesčiai už vizas.

${ }^{83}$ Jei pridetume ir užkardytą žalą dèl neteisèto rusiškų cigarečių įvežimo, remiantis $2010 \mathrm{~m}$. duomenimis (45 $\mathrm{mln}$. Lt.), tai suma išaugtų iki $115 \mathrm{mln}$. Lt. Papildomas išlaidas dar sudarytų neapskaičiuoti Lietuvos biudžeto praradimai dèl negautų pajamų už Lietuvoje realizuojamą neapskaitomą nelegaliai ir legaliai įvežtą kurą, alkoholị ir maisto prekes, patenkančias iš Rusijos (Kaliningrado srities).

${ }^{84}$ Lenteleje kai kurių nurodytų finansinių išraiškų dydis gali būti didesnis nei Lietuva gali tikètis tyrime aptartoms sritims ES 2014-2020 m. finansinëje perspektyvoje, todèl minètus skaičius galima vertinti kaip preliminarų ir greičiausiai dẻl politinių priežasčių koreguotiną institucinių ateities poreikių vertinimą.

${ }^{85}$ Interviu su Policijos departamento prie Lietuvos Respublikos vidaus reikalų ministerijos tarptautinio bendradarbiavimo valdybos vyriausiuoju specialistu p. Aleksandr Valentij, $2011 \mathrm{~m}$. vasario $19 \mathrm{~d}$.
} 


\section{Išvados}

Remiantis tyrimui iškeltomis užduotimis ir laukiamais analizès rezultatais buvo nustatytas numatomo bevizio režimo tarp Europos Sąungos ir Rusijos Federacijos įvedimo poveikis, kokybiškai ir kiekybiškai, atsižvelgiant ị šių dienų situaciją, ịvertintas poveikis Lietuvos vidaus reikalų sistemai; kartu buvo apibrežtos problemos, su kuriomis susidurtų Lietuvos valstybès sienos apsaugos sistema, Lietuvos migracijos valdymo sistema, Lietuvos policijos ir muitinès įstaigos įvedus bevizị režimą tarp ES ir Rusijos. Tiriant politinị bevizio režimo įvedimo kontekstą, galima konstatuoti, kad tai jau yra prasidęjęs procesas, o Lietuvoje, žinant šalies poveikio galimybes, instituciškai ir politiškai sutariama dèl režimo neišvengiamumo, Rusijos pažangos rodiklių, atsižvelgiant ị ES reikalavimus, matavimo ir ES neprisirišimo prie konkrečių bevizio režimo įvedimo terminų. Be to, beviziam režimui yra rezervuotas pritarimas Europos Sajungoje, siekiama, kad Rusija atliktų pirmuosius „namų darbus“ (panaikintų registraciją bei ịvestų biometrinius pasus). Reikia pažymèti, kad diskusijų ir derybų procese egzistuoja atsargesnių ir skeptiškesnių šalių grupe, kuriai priklauso Baltijos, Šiaurès šalys, naujosios ES narès ir Austrija, Jungtine Karalyste bei Olandija. Lietuvos nuostata, kad bevizis režimas Rusijai nebūtų ịvestas anksčiau, yra normatyviškai pagrịsta, tačiau nèra politiškai pasiekiama, nes bevizio režimo ịvedimas didžia dalimi priklausomas nuo bet kurios šalies pažangos: Rusijos atžvilgiu gali suveikti didžiųjų ES šalių politinè parama, kaip antai, nustatant šiai kaimyninei valstybei pigesnę vizų kainą nei, pvz., Rytų partnerystès šalims.

Šios mažos apimties studijos išvados ir pasiūlymai iš dalies orientuojami i ateities perspektyvas, o tai metodologiškai apsunkina tikslius vertinimus. Socialiniuose moksluose prognozès yra susijusios tik su tam tikrų veiksnių identifikavimu ir ju poveikio esant tam tikrai situacijai nustatymu. Šio tyrimo atveju užsakyme suformuotas tikslas ir uždaviniai orientuojami ị specifinius veiksnius bei jų poveiki, tačiau neatmestina, kad kompleksiškoje socialinëje realybeje gali pasireikšti ir kitų veiksnių, nętrauktų i studiją, poveikis, kuris čia nèra aptariamas dẻl tyrimo apimties ribotumo. Vertinant bevizio režimo poveiki legalios ir nelegalios migracijos mastams, galima teigti, jog dèl paprastesnès sienos kirtimo procedūros abipusés migracijos tendencijos sustiprès, o legali Rusijos piliečių migracija ị Lietuvą, tiek kaip ì galutinị, tiek kaip ị tarpinị kelionès tikslą padidès 2-3 kartus. Informacija apie būsimus nelegalios migracijos mastus yra ịvairi, tačiau teigti, kad nelegalios migracijos mastas didètų, nèra realaus pagrindo. Tikètina, jog Lietuvoje daugés Rusijos piliečiu, norinčiu igyti pabègèlio statusą. Nelegalių migrantų bei prieglobsčio prašytojų skaičiaus augimas, prognozuotina, padidintų su šiomis problemomis 
dirbančių tarnautojų darbo krūvius. Gali didèti rizika, kad Lietuva turès prisiimti atsakomybę už kitose ES šalyse pateiktus Rusijos prieglobsčio prašymus bei perimti tuos prieglobsčio prašytojus, kurie yra kirtę Lietuvos sieną.

Bevizis režimas panaikina specialiosios Kaliningrado tranzito schemos poreikị ir šios schemos finansavimą. Be to, ịvedus bevizį režimą ir dingus Rusijos piliečiu „filtrui“ Lietuvos konsulinėse ịstaigose, išaugtų per Lietuvos - Rusijos sieną vykstančių keleivių bei kartu transporto bei prekių (daiktų) srautai. Prognozuojant galima teigti, kad VSAT žmogiškuosius išteklius reikètų padidinti maždaug 215 papildomų pareigybių. ${ }^{86}$ LRM veiklos efektyvumui užtikrinti numatyta didinti žmogiškuosius išteklius, bet tikslių duomenų apie jų augimą vis dar trūksta. Remiantis Muitinès departamento pateiktais duomenimis, viename kontrolès punkte turètų dirbti 21 muitinès pareigūnas, siekiant užtikrinti efektyvią asmenų, transporto priemonių ir jomis gabenamų daiktų (prekių) muitinę kontrolę.

Lietuvos vidaus saugumui bevizis režimas turètų neigiamą įtaką: tai bendras nusikalstamumo didejjimas, organizuoto nusikalstamumo grupuočių veiklos intensyvejjimas bei terorizmo ir prekybos žmonèmis grésmių plitimas. Be to, Lietuvos-Rusijos sienos pažeidimų skaičiaus augimas, sulaikymų mastų ir nelegalaus akcizinių prekių gabenimo didejimas gali rodyti nusikalstamos veiklos augimo tikimybę. İvardytos grésmès reikalautu papildomų žmogiškujjų (78 papildomų pareigybių) bei finansinių išteklių. Studija atskleidẻ naujų teisinių priemonių, padesiančių bendradarbiauti Lietuvos ir Rusijos, ES ir Rusijos pareigūnams, reikalingumą vidaus saugumo užtikrinimo srityje.

Apibendrinant svarbu akcentuoti, kad Europos Sąjungos - Rusijos bevizio režimo įvedimo sąnaudos susideda iš dviejų dalių: pirma, tai sąnaudos, susijusios su nuostoliais dèl sumažejusio ES finansavimo, ir negautos lěšos. Tai per metus sudarytų per $70 \mathrm{mln}$. litų ir net galbūt daugiau, ịtraukiant praradimus dèl negautų pajamų už Lietuvoje realizuojamas nelegaliai ir legaliai ịvežtas prekes. Antra, prognozuojamos išlaidos, kurių apibendrinimas yra pateiktas žemiau esančioje lentelëje.

Galiausia reikia pažymèti, kad Kaliningrado srities išskirtinumas taip pat yra svarbus aspektas: viena vertus, Lietuvoje yra politinių nuostatų Kaliningrado sričiai suteikti daugiau išskirtinumo judejjimo, atvirumo srityje, tačiau, antra vertus, dèl migracijos iš šios srities ir ekonominio išsivystymo netolygumų Lietuvos ekonomika šalies pasienyje, tikètina, patirs papildomą spaudimą.

\footnotetext{
${ }^{86}$ Interviu su p. Audriumi Pauliukevičiumi (47 išnaša).
} 


\section{1 lentelè. Bendra preliminari ES-Rusijos Federacijos}

bevizio režimo ịvedimo finansinè našta Lietuvai, litais

\begin{tabular}{|c|c|c|c|}
\hline & $\begin{array}{l}\text { Metinès } \\
\text { sąnaudos }\end{array}$ & $\begin{array}{l}\text { Papildomos } \\
\text { sąnaudos }\end{array}$ & $\begin{array}{c}\text { Numatomi } \\
\text { ateities } \\
\text { projektai }\end{array}$ \\
\hline \multicolumn{4}{|l|}{ Sąnaudų rūšis pagal veiklos sritis } \\
\hline \multicolumn{4}{|l|}{ 1. Sienos apsaugos organizavimas } \\
\hline 1.1. Papildomų VSAT pareigybių išlaikymas & 10750000 & & \\
\hline $\begin{array}{l}\text { 1.2. Pasienio kontrolès punktụ } \\
\text { modernizacija }\end{array}$ & & 17000000 & \\
\hline 1.3. Tilto Panemunè-Sovetskas statyba & & & 45000000 \\
\hline \multicolumn{4}{|l|}{ 2. Muitinès veiklos organizavimas } \\
\hline 2.1. Muitinès postų modernizavimas & & 2400000 & \\
\hline $\begin{array}{l}\text { 2.2. Rentgeno kontrolès sistemos (RKS) } \\
\text { irengimas }\end{array}$ & $\begin{array}{c}400000 \\
(1200000)^{1}\end{array}$ & $14000000^{2}$ & 40000000 \\
\hline 2.3 Muitinès mobiliųu grupių (MMG) ịranga & & 1900000 & \\
\hline 2.4. Papildomų MMG pareigybių išlaikymas & 658500 & & \\
\hline 2.5. Pareigūnų uniforminè apranga & & 60000 & \\
\hline \multicolumn{4}{|l|}{ 3. Policijos veiklos organizavimas } \\
\hline $\begin{array}{l}\text { 3.1. Kriminalinès policijos papildomų parei- } \\
\text { gybių išlaikymas }\end{array}$ & 1026200 & 650284 & \\
\hline $\begin{array}{l}\text { 3.2. Viešosios policijos papildomų pareigy- } \\
\text { bių išlaikymas }\end{array}$ & 1213950 & 946384 & \\
\hline 3.3. IT bazès atnaujinimas (POLIS) ${ }^{3}$ & & 500000 & \\
\hline $\begin{array}{l}\text { 3.4. Biologinio, cheminio ir radioaktyvios } \\
\text { taršos nustatymo ịrenginių ịsigijimas }\end{array}$ & & 350000 & \\
\hline 3.6. „ARO“ techninè įranga & & 2361500 & \\
\hline $\begin{array}{l}\text { 3.7. Specialios tranzito schemos ịrangos } \\
\text { eksploatacija }\end{array}$ & $1184000^{4}$ & & \\
\hline \multicolumn{4}{|l|}{$\begin{array}{l}\text { 4. Prieglobsčio prašymo sistemos veiklos } \\
\text { organizavimas }\end{array}$} \\
\hline 4.1. Prieglobsčio prašymo procedūros & $1000000^{5}$ & & \\
\hline $\begin{array}{l}\text { 4.2. Užsieniečių išlaikymas Užsieniečių } \\
\text { registracijos centre }\end{array}$ & $282000^{6}$ & & \\
\hline 5. Iš viso & $\begin{array}{c}16514650 \\
(17314650)\end{array}$ & 40168168 & 85000000 \\
\hline
\end{tabular}

Šaltinis: autorių surinkti duomenys

\footnotetext{
${ }^{1}$ Tokia suma susidarytų, jei veiktų ne 2 , bet 6 stacionarios rentgeno kontroles sistemos.

2 Planuojamas finansavimo šaltinis - Europos kaimynystès ir partnerystés priemone „Lietuvos, Lenkijos ir Rusijos bendradarbiavimo per sieną programa“ (dabartinè būklè - programos Jungtiniam techniniam sekretoriatui pateikta paraiška).

${ }^{3}$ Pastaba: paprastumo dèlei pateikiamos sąnaudos be papildomų išlaidų, kurios galètų sudaryti nuo 100000 iki $4 \mathrm{mln}$. litų.

${ }^{4}$ Pastaba: apskaičiuota remiantis $2011 \mathrm{~m}$. prognozemis.

${ }^{5}$ Pastaba: apskaičiuota remiantis metiniais $2010 \mathrm{~m}$. duomenimis apie prieglobsčio prašymo nagrinejjimo ir asmens, gavusio prieglobstị, integracijos išlaidas.

${ }^{6}$ Pastaba: apskaičiuota remiantis metiniais 2010 m. duomenimis apie užsieniečių išlaikymą Užsieniečių registracijos centre.
} 


\section{Rekomendacijos}

Atlikus analizę ir apskaičiavus bevizio režimo įvedimo finansinę išraišką, šioje dalyje bus siūlomi galimi numatomų problemų sprendimo būdai ir tam tikros iššūkių valdymo, švelninimo priemonès. Visgi reikia pažymèti, kad praktikoje sunku neutralizuoti visus padarinius, kadangi jos yra kompleksiškos ir turi ilgalaikị socialinį ir ekonominị poveikį ne vien Lietuvos vidaus reikalų sistemai, bet ir platesniu šalies ar ES mastu. Be to, tyrime yra įvertinamos tik ES-Rusijos bevizio režimo sąnaudos, tačiau nenagrinëjama galima bevizio režimo finansine ir kitokia nauda, kuria yra suinteresuotos Ūkio ministerija ir ypač prie jos esantis Turizmo departamentas - tai galètų būti ateities tyrimų uždavinys.

Politiškai ir istoriškai santykiai su Rusija visada buvo viena svarbiausių vidaus ir užsienio darbotvarkés problemų Lietuvoje. Galių asimetrija, identiteto sankirtos, skirtinga gyvosios atminties interpretacija, taip pat ekonominès tarpusavio priklausomybès ir energetinių šaltinių problemos suponuoja aktyviai konstruoti santykius su Rusija, pasinaudojant ES struktūra ir ieškant partnerių ES. Todèl šiame tyrime analizuojamos temos srityje reikia išnaudoti esamas ir kuriamas bendradarbiavimo galimybes su šalimis, turinčiomis panašius interesus, t.y. visų pirma su Baltijos ir Šiaures kaimynemis, Lenkija, atkreipiant dèmesị į NB8+1 (Baltijos, Šiaurès ir Jungtinès Karalystes šalių formata) ir su skeptiškai nusiteikusiomis bevizio režimo atžvilgiu ES naremis. Rekomenduotina ir toliau siekti bevizio režimo įvedimu susijusių priemonių igyvendinimo Rusijoje, taip pat šios šalies pažangos matavimo bei pirminių jos „namų darbų“ atlikimo, siekiant, kad kuo didesnè šalių grupe ir EK laikytųsi šių pozicijų.

Artëjant 2014-2020 m. finansinei perspektyvai, kuomet Lietuvos institucijos pateiks finansiškai pagrịstus poreikius naujam programavimo laikotarpiui, žvelgiant ị administracines priemones ir žmogiškuosius išteklius verta numatyti kompensacinių priemonių ar perkvalifikavimo įtraukimą žmonèms, kurie neteks darbo nustojus veikti specialiajai Kaliningrado tranzito schemai. Rekomenduojama finansinemis ir administracinemis priemonèmis stiprinti Lietuvos-Rusijos sienos apsaugą, Lietuvos muitinę, vidaus saugumu ir prieglobsčio sistema besirūpinančių Lietuvos institucijų funkcijas, taip pat jų suderinamumo, ypač informacijos apsikeitimo srityje, pletrą. Vienas iš galimų pasiūlymų - parengti tarpinstitucini veiklos planą, kuriame būtų numatomos bendros grèsmių neutralizavimo ir prevencijos priemoniu gaires ${ }^{87}$. Reiketų imtis prevencinių išankstinès patikros priemonių, apsaugančių nuo asmenų piktnaudžiavimo prieglobsčio prašymu ir,

\footnotetext{
${ }^{87}$ Interviu su p. Audrone Sviklaite, 2011 m. sausio 31 d. (išnaša 56)
} 
keičiantis informacija tarp pasienyje veikiančių institucijų, užkirsti kelią kirsti sieną asmenims, kurie yra prašęsi prieglobsčio ir ateityje gali tuo piktnaudžiauti. ${ }^{88}$ Taip pat patartina vystyti dvišalį bendradarbiavimą abipus sienos tarp Lietuvos ir Rusijos bei ES ir Rusijos atitinkamų institucijų tyrimo apžvelgtose srityse ${ }^{89}$ ir siekti abipusio suinteresuotumo dèl neigiamų padarinių neutralizavimo. Taigi vienas iš pasiūlymų - Rusijos ịpareigojimas ịgyvendinti supaprastintas jos piliečių grąžinimo ị tèvynę procedūras. ${ }^{90}$ Lietuva, be to, turi siekti ES ir Rusijos susitarimuose įtvirtinti nuostatą, pabrěžiančią abipusị sienos pralaidumo didinimą, siekiant išvengti diskriminacijos iš Rusijos pusès.

Galiausiai analizuojamame bevizio režimo tarp Europos Sąungos bei Rusijos Federacijos kontekste nemažos svarbos igyja ir gerosios praktikos pavyzdžiai. Vienas iš tokiu - Electronic System for Travel Authorization (ESTA), naudojama JAV. ${ }^{91}$ Sistemos esmę sudaro piliečių, norinčių keliauti i j JAV, registravimas automatinëje sistemoje ir leidimų suteikimas. Europos Sajungoje analogiško mechanizmo nèra, tačiau Lietuvai būtų naudinga įvairiais ES lygmenimis siūlyti išanalizuoti tokios sistemos įvedimo galimybę įvedus bevizị režimą. Siekiant užtikrinti šių prekių muitinès kontrolę, kad jos nesankcionuotai nepatektų i ES muitų teritoriją, būtų tikslinga asmenu gabenamiems daiktams taikyti specialų muitinès priežiūros režimą. Šios priemonès turetų būti finansuojamos iš ES, igyvendinant specialią tranzito schemą (arba analogišką) programą, o šis klausimas turi būti aptartas ir reglamentuotas ES lygiu.

\section{1 lapkritis}

\footnotetext{
${ }^{88}$ Ten pat.

${ }^{89}$ Pvz., sudaryti dvišalę sutartį su Rusija dèl kovos su organizuotu nusikalstamumu, kuri užtikrintų efektyvesnį keitimąsi informacija; sudaryti žemesnio lygmens (tarpžinybinę) sutartị Vidaus reikalų, Finansų ministerijų lygiu, kuri palengvintų bendradarbiavimą su atitinkamomis Kaliningrado srities institucijomis po bevizio režimo įvedimo; ES lygiu pasirašyti Europolo bei atitinkamų Rusijos institucijų sutartį, kuri leistų vykdyti bendrus tyrimus, sudarytų sąlygas keistis asmens duomenimis, kartu užtikrinant tokių duomenų apsaugos didinimą Rusijoje.

${ }^{90}$ Interviu su p. Antanu Turčinu, $2011 \mathrm{~m}$. sausio $27 \mathrm{~d}$.

${ }^{91}$ Interviu su Lietuvos Respublikos vidaus reikalų ministerijos Tarptautinio bendradarbiavimo departamento direktoriumi p. Olegu Skinderskiu, 2010 m. gruodžio 8 d.
} 